\title{
Resistance mechanisms of wild tomato germplasm to infection of Oidium neolycopersici
}

\author{
Aleš Lebeda • Barbora Mieslerová • Marek Petřivalský • \\ Lenka Luhová • Martina Špundová • Michaela Sedlářová • \\ Vladimíra Nožková-Hlaváčková • David A. C. Pink
}

Accepted: 24 September 2013 / Published online: 31 October 2013

(C) KNPV 2013

\begin{abstract}
Tomato powdery mildew (Oidium neolycopersici) is one of the most devastating diseases of cultivated tomatoes worldwide. Although the first epidemics were recorded more than 25 years ago many aspects of this host-pathogen interaction are still not well understood. Detailed morphological and molecular studies of the anamorphs confirmed that $O$. neolycopersici is phylogeneticaly close to Erysiphe aquilegiae var. ranunculi. Host range is rather broad, apart from Solanaceae hosts were found in the families Apocynaceae, Campanulaceae, Crassulaceae, Cistaceae, Cucurbitaceae, Linaceae, Malvaceae, Papaveraceae, Pedialiaceae, Scrophulariaceae, Valerianaceae a Violaceae. Non-host resistance within these
\end{abstract}

A. Lebeda $(\bowtie) \cdot$ B. Mieslerová $\cdot$ M. Sedlářová

Department of Botany, Faculty of Science, Palacký

University in Olomouc,

Šlechtitelů 11, 78371 Olomouc-Holice, Czech Republic

e-mail: ales.lebeda@upol.cz

M. Petřivalský $\cdot$ L. Luhová

Department of Biochemistry, Faculty of Science, Palacký

University in Olomouc,

Šlechtitelů 11, 78371 Olomouc-Holice, Czech Republic

M. Špundová • V. Nožková-Hlaváčková

Centre of the Region Haná for Biotechnological and

Agricultural Research, Department of Biophysics, Faculty

of Science, Palacký University in Olomouc,

Šlechtitelů 11, 78371 Olomouc-Holice, Czech Republic

D. A. C. Pink

Harper Adams University,

Newport, Shropshire TF10 8NB, UK families is not based on inhibition of formation of primary haustorium, however, on post-haustorial hypersensitive reponse and another type of non-hypersensitive resistance. Screening of wild Solanum species (previous Lycopersicon spp.) germplasm revealed valuable sources of resistance (S. habrochaites, S. pennellii, S. cheesmaniae, S. chilense, S. peruvianum). The main resistance mechanism was found to be a hypersensitive response (HR), in some cases followed by limited development of the pathogen. However, there is a broad variation in resistance response on the histological and cytological level. Interaction between many wild Solanum spp. and $O$. neolycopersici is race-specific, at least three races were differentiated. In some interspecific crosses (S. lycopersicum $\times S$. habrochaites) adult plant resistance was observed. Biochemical studies focusing on production of reactive oxygen species (ROS) and peroxidase activity during infection of $O$. neolycopersici showed that production of ROS and activity of corresponding enzymes is related to activation of defence responses in genotypes of wild Solanum sect. Lycopersicon. The significance of nitric oxide (NO) in O. neolycopersici pathogenesis was supported by experiments with NO donors and scavengers. In moderately resistant genotype $S$. chmielewskii, treatment by heat stress caused slight deceleration of pathogen development, increased production of jasmonic acid (JA) and abscisic acid (ABA) and increased peroxidase activity in infected plants. The different degree of tomato resistance/ susceptibility did not markedly change the rate and extent of photosynthetic response to O. neolycopersici; only minimal impairment of photosynthesis was found in both susceptible and moderately resistant genotypes during the 
first 9 days after inoculation. The accumulated evidence confirm a crucial role of localised increased production of ROS and reactive nitrogen species (RNS) in response to pathogen penetration into plant tissue and its involvement in the plant resistance responses including the initiation and progression of plant cell death in host wild Solanum species. Crucial points of further research are discussed.

Keywords Disease resistance - Genetics of resistance . Host range $\cdot$ Hypersensitive response $\cdot$ Infection cycle $\cdot$ Nonhost resistance Plant hormones .

Photosynthesis $\cdot$ Race-specificity $\cdot$ Reactive oxygen and nitrogen species $\cdot$ Solanum spp. $\cdot$ Tomato powdery mildew . Virulence variability

\section{Introduction}

The tomato and its close wild relatives originate in the mountainous regions of the Andes and the Galapagos Islands (Ji and Scott 2007). Tomato (Solanum lycopersicum) is a perennial plant, but cultivated as annual crop, growing world-wide (Rubatzky and Yamaguchi 1997; Heuvelink 2005). The original taxonomic classification within the genus Lycopersicon described nine species (Rick 1995). Now the genus Solanum has been broadened to include according to various sources between 1,500-2,000 species (Knapp et al. 2004). Cultivated tomato can be placed in the subgenus Solanum sensu stricto, section Lycopersicon, alongside 12 closely related species. The other related species belong to section Juglandifolia (Solanum ochranthum, Solanum juglandifolium) and Lycopersicoides (Solanum lycopersicoides, Solanum sitiens) (Peralta et al. 2008).

A lot of diseases have been described on tomato (Dixon 1981; Macnab and Sherf 1986; Blancard 1992; Koike et al. 2007) and many of them are very devastating. A smaller number have a worldwide distribution and a huge economic impact. Tomato powdery mildew, caused by Oidium neolycopersici (Kiss et al. 2001) is a relatively new disease, which occurs mainly on glasshouse tomato crops. From the 1980s, when the first epidemics of powdery mildew were recorded in Western Europe, the pathogen rapidly spread through the whole of Europe and also to the countries of the New World (Mieslerová and Lebeda 1999). Until now only the asexual state of the disease causing organism has been found.
In 1990s experimental studies concerning Oidium neolycopersici focused mainly on the morphological and molecular characterisation of this pathogen (Whipps et al. 1998; Lebeda and Mieslerová 1999; Jones et al. 2000; Kiss et al. 2001; Mieslerová et al. 2002), its host range (Whipps et al. 1998; Lebeda and Mieslerová 1999; Lemaire et al. 1999; Huang et al. 2000a) and searching for resistance sources within indigenous genus Lycopersicon (Lindhout et al. 1994a; Kumar et al. 1995; Ignatova et al. 1997; Milotay and Dormanns-Simon 1997; Ciccarese et al. 1998; Mieslerová et al. 2000).

Later attention was focused on study of resistance mechanims after infection of $O$. neolycopersici at the histological, biochemical and photosynthetic level (Huang et al. 1998; Mieslerová et al. 2004; Mličková et al. 2004; Tománková et al. 2006; Piterková et al. 2009, 2011; Prokopová et al. 2010; Nožková-Hlaváčková et al., submitted). Research in the last 15 years has broadened knowledge of the genetic basis of resistance to O. neolycopersici (Lindhout et al. 1994b; Ciccarese et al. 1998; Huang et al. 2000b; Bai et al. 2003, 2004, 2005; Li et al. 2006, 2007, 2008, 2012; Seifi et al. 2013).

The current review is focused on the most recent aspects of pathogen taxonomy and biology, variability of host-pathogen interactions, variation of virulence, sources of resistance in wild Solanum spp., mechanisms of resistance of host plants, breeding for resistance. The aims of this paper are to summarize the current information on $O$. neolycopersici, critically discuss the areas of host resistance and how resistance is orchestrated, and introduce them in the wider context of biotrophic parasitism within powdery mildews.

\section{Host and pathogen taxonomy and diversity}

\section{Solanum (Lycopersicon) spp.}

Solanum spp. form a large and diverse genus of annual and perennial plants. They grow as herbs, vines, >subshrubs, shrubs, and small trees, and often have attractive fruit and flowers. Many formerly independent genera like Lycopersicon (the tomatoes) or Cyphomandra are now included in Solanum as subgenera or sections. Thus, the genus nowadays contains roughly 1,500-2,000 species (Peralta et al. 2008). When devastating disease epidemics appeared on glasshouse tomato crops in Western Europe, wild species previously classified in the genus of 
Lycopersicon were screened for sources of resistance to $O$. neolycopersici (Lebeda and Mieslerová 1999; Mieslerová et al. 2000).

According to the former concept of Rick $(1979,1995)$ two large species-complexes were discriminated within genus Lycopersicon, namely Esculentum-complex and Peruvianum-complex. The Esculentum-complex encompassed seven species: L. esculentum (newly Solanum lycopersicum), L. cheesmanii (S. cheesmaniae), L. chmielewskii (S. chmielewskii), L. hirsutum (S. habrochaites), L. parviflorum (S. neorickii), L. pennellii (S. pennellii) and L. pimpinellifolium ( $S$. pimpinellifolium). In the Peruvianum-complex were placed two species: $L$. chilense ( $S$. chilense) and $L$. peruvianum (S. peruvianum).

In primal conception there was found crossability among all species, although some hybrids were obtained only unilaterally (occurrence of unilateral compatibility) (Rick 1995). The situation is more complicated in Peruvianum-complex because hybrids between representatives of Esculentum and Peruvianum-complexes can be obtained only hardly, and according to Rick (1979) only by using of embryocultures. One possibility is using of genotypes-bridges (Poysa 1990), which are interspecific hybrids, well crossable with representatives of Peruvianum-complex as well as Esculentum-complex.

Recently, it is widely accepted that tomato and its wild relatives belong to the genus Solanum subgen. Potatoe (G. Don) D’Arcy, sect. Lycopersicon (Mill.) Wettst., subsect. Lycopersicon (e.g. Child 1990; Spooner et al. 2005; Ji and Scott 2007; Peralta et al. 2008) and are divided to the three series Lycopersicon, Eriopersicon (C.H. Müll.) Child, and Neolycopersicon (Corell) Chil. Child (1990) also propounded representatives of Solanum sect. Lycopersicon (Mill.) Wettst., subsect. Lycopersicoides Child (including S. lycopersicoides and S. sitiens), and sect. Juglandifolium (Rydb.) Child (included S. juglandifolium and $S$. ochranthum) as the closest relatives of subsect. Lycopersicon. Another change opposite to earlier conception is the name of the new species $S$. galapagense, earlier named as $S$. cheesmaniae f. minor (Peralta and Spooner 2005) and species $S$. arcanum and S. huaylasense, derived from former species $S$. peruvianum (Peralta et al. 2005). Peralta et al. (2008) recently distinguished 13 species belonging to Solanum sect. Lycopersicon and four closely related species ( $S$. juglandifolium, $S$. lycopersicoides, $S$. ochranthum and $S$. sitiens). Table 1 shows comparison of the classification of genus Solanum sect. Lycopersicon with earlier classification systems.
Tomato powdery mildew (Oidium neolycopersici)

Tomato powdery mildew (Oidium neolycopersici) belongs to the order Erysiphales (powdery mildews) within the Ascomycetes (Sac Fungi). Powdery mildews are parasitic fungi which infect and cause substantial economic losses on a wide range of agricultural and horticultural plants. All powdery mildews are obligate parasites (Ridout 2009) and belong to the order Erysiphales (Braun and Cook 2012). There are almost 10,000 host species worldwide and over 700 species of powdery mildews (Braun and Cook 2012). These obligate biotrophs are very easily identified because of their extramatrical (superficial) mostly white mycelium covering the surface of green parts of plants (leaves, stems, petioles, and in some cases also fruits). However, identifying the exact species is difficult. This fact coincides with the new findings in taxonomy of this group. The most recent monograph is bringing the new concepts to the taxonomy of powdery mildews (Braun and Cook 2012).

Formerly the resolution of powdery mildews to the genera was based on features of teleomorph states (number of asci in ascocarp and structure of appendages), while features of anamorph state were neglected (Leveillé 1851). This approach was accepted by Salmon (1900), Blumer (1967), Braun (1987, 1995). Now, results of molecular genetic studies have led to substantial changes. The one of the most obvious examples is different concept of genus Erysiphe. From wider concept of Erysiphe sensu lato, which was before considered as polyphyletic (Saenz and Taylor 1999; Takamatsu et al. 1999), on the base of molecular phylogenetic analysis the previous sections Galeopsidis, Erysiphe and Golovinomyces was promoted on the generic level (Braun 1999; Braun and Takamatsu 2000; Braun et al. 2002) and introduced new genera, namely Neoerysiphe (prev. Erysiphe sect. Galeopsidis) and Golovinomyces (prev. Erysiphe sect. Golovinomyces). On the other hand, Erysiphe sect. Erysiphe, Microsphaera (incl. Bulbomicrosphaera and Medusosphaera) and Uncinula (incl. Bulbouncinula, Furcouncinula and Uncinuliella), all with very similar anamorph (Pseudoidium type) were fused to the genus Erysiphe emend. and diverged into three morphological, nonphylogenetic sections, namely Microsphaera, sect. Uncinula and sect. Erysiphe (Braun and Takamatsu 2000). 
Table 1 Comparison of earlier (Rick 1979) and recent classification (Peralta et al. 2008) of genus Solanum sect. Lycopersicon (according to Grandillo et al. 2011)

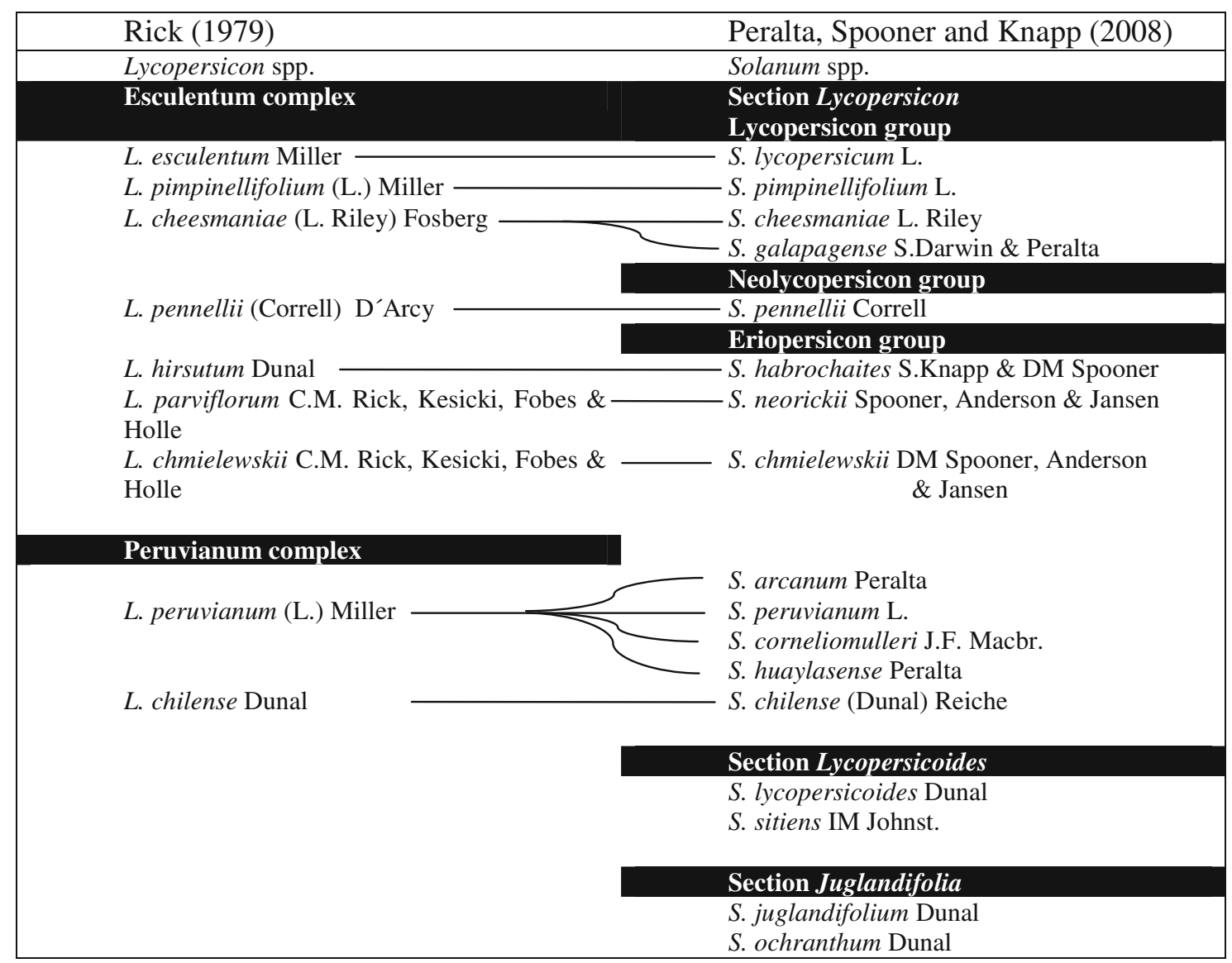

These changes consequently had impact on the view on taxonomic position of Oidium neolycopersici. In the end of the 19th century, Cooke and Massee (1888) recorded in Australia the new powdery mildew species, which was named as Oidium lycopersicum. When devastating epidemics of powdery mildews on tomatoes started in the 1980's, Noordeloos and Loerakker (1989) on the basis of morphological comparative studies named this species as Oidium lycopersicum. Later, Kiss et al. (2001) distinguished original species described on tomatoes in Australia (O. lycopersicum; placed in Oidium subgen. Reticuloidium, corresponds to teleomorph Golovinomyces spp.) from the species which is responsible to infestation of tomatoes in Europe, Africa, North and South America and Asia, which was called Oidium neolycopersici (placed in Oidium subgen. Pseudoidium, which corresponds to teleomorph of the genus Erysiphe sect. Erysiphe). Then, Kiss et al. (2005) confirmed the identity of Oidium neolycopersici isolates originated from the North America as $O$. neolycopersici on the basis of molecular and morphological data.

Till now the teleomorph state of this pathogen has not been found, however according to comparative study including light microscopy, scanning electron microscopy (SEM) and ITS sequence analysis, Jones et al. (2000) placed this fungus to genus Erysiphe sect. Erysiphe, very close (genome is nearly identical) to species Erysiphe aquilegiae var. ranunculi and on the contrary very distant from Erysiphe orontii (newly Golovinomyces orontii). Similar results were confirmed by Kiss et al. (2001) (Fig. 1). Detailed morphological characteristics of this species were given by Braun (1995), Mieslerová and Lebeda (1999), Mieslerová et al. (2002) (Figs. 2 and 3). 


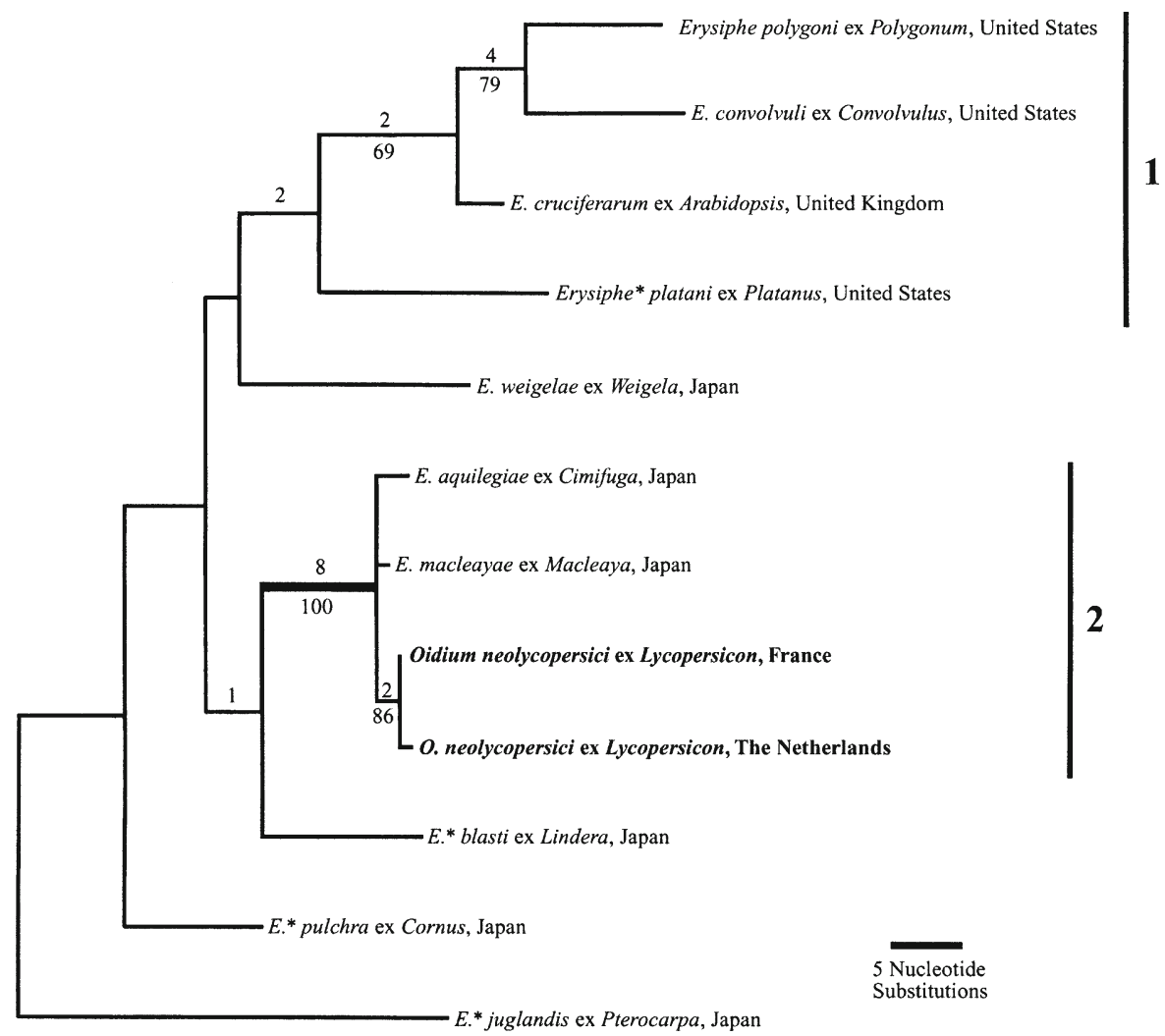

Fig. 1 Phylogenetic analysis of the internal transcribed spacer (ITS) region of the ribosomal RNA gene for 12 Pseudoidium anamorphs (according to Kiss et al. 2001)

\section{Intraspecific variability of O. neolycopersici}

In the study of intraspecific variability of tomato powdery mildew based on susceptibility/resistance of host genotypes there is only limited usage of commercial cultivars of tomato, because they are mostly susceptible (Kozik 1993; Lindhout et al. 1994a; Mieslerová et al. 2000). Some wild relatives of tomato include valuable
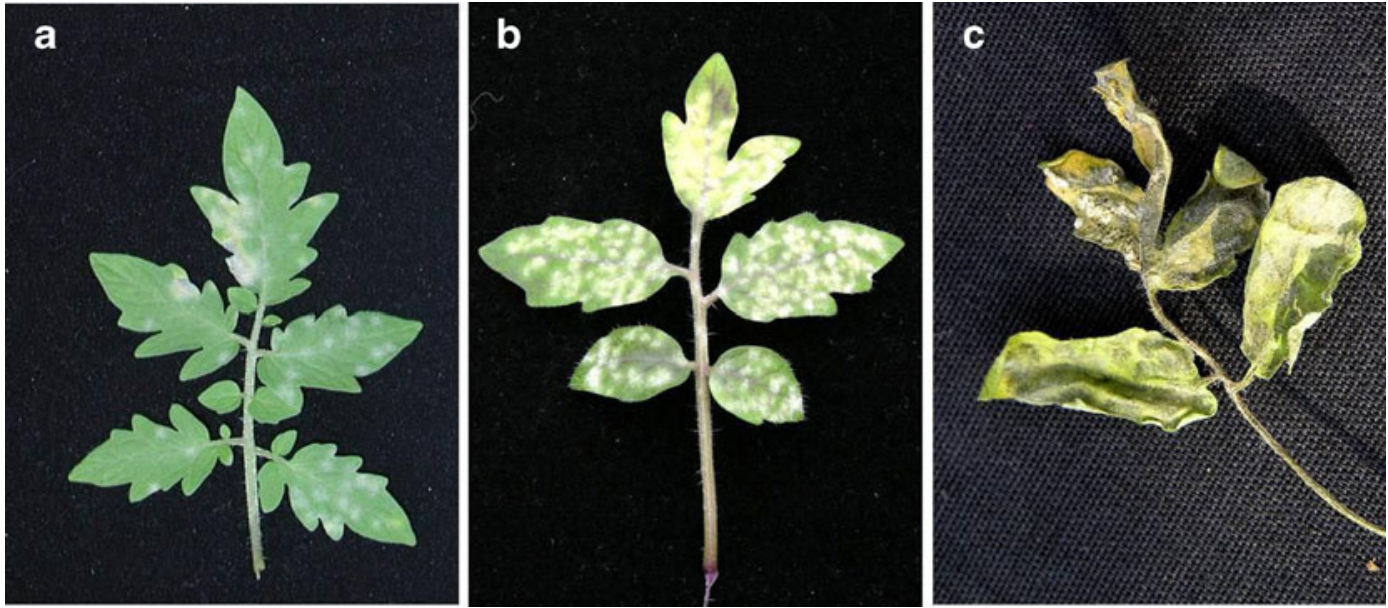

Fig. 2 Symptoms of tomato powdery mildew (O. neolycopersici) infection on susceptible $S$. lycopersicum. a The initial symptoms of powdery mildew. b Intensive disease infestation. c Necrosis after intensive disease development. (photo B. Mieslerová) 

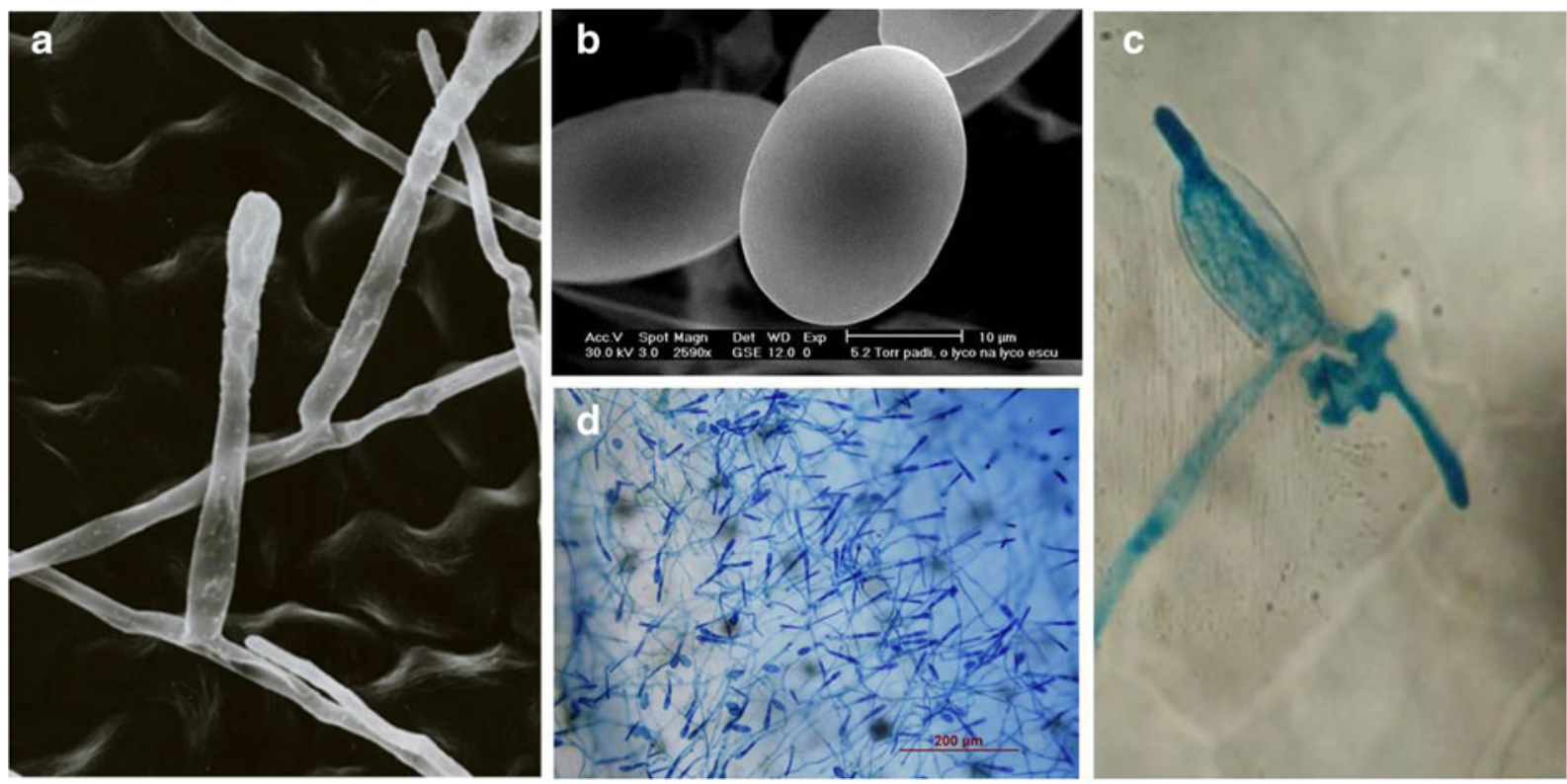

Fig. 3 Tomato powdery mildew (Oidium neolycopersici). a Conidiophores. b Conidia. c Germinating conidium. d Dense mycelial coat with conidiophores on leaf of susceptible tomato. (photo R. Novotný $(\mathbf{a}, \mathbf{b})$ and B. Mieslerová (c, d))

sources of resistance and tomato lines have been produced from crosses with these wild species (Bai et al. 2005). Study of pathogenic variability is still limited. Firstly, it is difficult to obtain and maintain defined isolates of powdery mildew, and the different published studies have not used identical host genotypes. Detected differences, which have been used to postulate the existence different formae speciales, need verification (Huang et al. 1998; Mieslerová and Lebeda 1999).

One of the most detailed study of the intraspecific variability of $O$. neolycopersici on the basis of differences in pathogenicity was made by Lebeda and Mieslerová (2002), who studied the virulence of four isolates of $O$. neolycopersici originating from the Czech Republic, Germany, the Netherlands and England on 35 representatives of genus Lycopersicon (now Solanum sect. Lycopersicon). Variability was found among these four isolates. The most differential was the isolate originating from England, due to its high virulence on the set of genotypes used in the study. On the basis of previous studies of $O$. neolycopersici a differentiated set of Lycopersicon spp. genotypes was proposed (Lebeda and Mieslerová 2002).

The existence of pathogen races was also shown by Kashimoto et al. (2003b), who recorded that Japanese isolate KTP-01 was able to infect resistant tomato cultivar Grace, originating from the Netherland.
Another approach to study intraspecific variability of $O$. neolycopersici is the application of molecular genetic methods. Use of AFLP markers differentiated four O. neolycopersici isolates (Huang et al. 1998) and the results showed at least two different types of $O$. neolycopersici isolates in the Netherlands. Unfortunately, this research was not followed by a virulence variability study. Kovács et al. (2011) confirmed differences in nrDNA ITS sequences by $O$. neolycopersici, where three to four types of ITS were observed.

Study of intraspecific variability of 10 Oidium neolycopersici isolates originating from various countries of Europe, North America and Japan showed that ITS sequences were identical for all 10 isolates, however AFLP analysis discovered a high level of diversity in the isolates and they were represented by different genotypes (Jankovics et al. 2008). The reason why isolates were identical based on ITS, but very different based on AFLP fingerprinting, might be due to the fact that PM genomes are largely occupied by repetitive sequences (Spanu 2012), thus many differences could be detected by AFLP in those regions. However, until now no clear relationship between virulence and AFLP patterns of $O$. neolycopersici isolates has been found. The same study also compared anamorphs of $O$. neolycopersici and powdery mildews from host plants Aquilegia vulgaris, Chelidonium majus, Passiflora 
caerulea and Sedum alboroseum, but anamorphs of these species could not be distinguished morphologically, and they were phylogenetically very close to $O$. neolycopersici. All those species (anamorphs) of powdery mildew were virulent only on their original host species, except $O$. neolycopersici, which was able to infect $S$. alboroseum, tobacco, petunia and Arabidopsis thalliana (Jankovics et al. 2008).

In this area of research the most difficult problem is the separate studies of intraspecific variation by molecular genetic methods and by virulence variation. It is therefore important to develop closer cooperation between the two approaches.

\section{Host-pathogen interactions}

Symptoms of infection

The first symptoms of disease start to appear in early summer, occasionally at the end of spring. The primary symptoms of white circular pustules occur mainly on the upper sides of leaves and often spread onto petioles and stems. The younger leaves are mostly without symptoms. Colonies of powdery mildews are initially small, 3-10 $\mathrm{mm}$ in average, and then coalesce and finally mycelium can cover the whole leaf (Fig. 2). In severly attacked plants, powdery mildew can be found also on the lower side of leaves, on petioles and stalks; however, it has never been found on fruits. The infected parts of plants grow slower, and often become chlorotic (Mieslerová and Lebeda 1999).

The occurrence of the disease is recorded mainly on glasshouse tomato crops although records from the field are also known (Mieslerová and Lebeda 1999).

\section{Host range of $O$. neolycopersici}

Many authors describe experiments studying the host range of $O$. neolycopersici. The first hypothesis stated that tomato powdery mildew is a strain of powdery mildew occurring on cucurbitaceous species (namely Erysiphe orontii, recently Golovinomyces orontii), which had spread to a new host. This hypothesis was initially supported by the results of a study of the host range of tomato powdery mildew, in which successful transfer on cucurbits (Corbaz 1993) was confirmed. One of the most extensive studies of the host range of O. neolycopersici was made by Whipps et al. (1998), who screened representatives of more than 26 plant families, which were known as a hosts of Erysiphe orontii (recently Golovinomyces orontii). They also proposed the hypothesis that $O$. neolycopersici could be a race or strain of $G$. orontii. However, from a morphological point of view based on features of the anamorph state (differences in formation of conidiophores, differing on Pseudoidium and Euoidium groups) these two species are different; however this study still contributed greatly to extending the knowledge about the host range of $O$. neolycopersici.

It was found that $O$. neolycopersici is not able to infect economically important species from the families Brassicaceae (Brassica oleracea var. botrytis; Brassica oleracea var. capitata), Compositae (Asteraceae), Leguminosae (Phaseolus lunatus, Pisum sativum) and Poaceae (Zea mays, Triticum aestivum) (Arredondo et al. 1996; Whipps et al. 1998). On the other hand, some susceptible species were found in the families Apocynaceae, Campanulaceae, Crassulaceae, Cistaceae, Linaceae, Malvaceae, Papaveraceae, Pedialiaceae, Scrophulariaceae, Valerianaceae a Violaceae (Whipps et al. 1998).

The most interesting findings were the results concerning the family Solanaceae which confirmed the completely resistant genotypes of Ancistus parviflorus, Atropa sp., Browalia sp., most of the representatives of Capsicum spp., Hyoscyamus albus, $H$. niger, some species of the genus Solanum, e.g. $S$. aculeatissimum, S. argentinum, S. capsicastrum, $S$. giganteum, S. juglandifolium, S. macrocarpon, $S$. mauritianum, S. rostratum, S. labrum, S. tucumanense. These were followed by some moderatelly resistant genotypes of Datura metaloides, Lycium sp., Physalis alkekengi, P. minima, some species of Solanum (S. aethiopicum, S. chenopodioides, S. incanum, $S$. tuberosum, S. villosum). At the other end of this spectrum were susceptible genotypes of genera Datura sp., Nicotiana sp., Petunia sp., Schizanthus sp., and Solanum capsicoides, $S$. jamaicense, $S$. laciniatum, $S$. lycopersicoides, S. melongena, S. sysimbriifolium (Fletcher et al. 1988; Arredondo et al. 1996; Ignatova et al. 1997; Smith et al. 1997; Whipps et al. 1998; Lebeda and Mieslerová 1999; Huang et al. 2000a).

Some experiments have confirmed the ability of $O$. neolycopersici to infect representatives of Cucurbitaceae (Angelov a Georgiev 1993; Corbaz 1993; Ignatova et al. 1997; Whipps et al. 1998; Lebeda a Mieslerová 1999). These results are in contrast with those of 
Fletcher et al. (1988) and Kashimoto et al. (2003a), who found that Oidium neolycopersici cannot be transferred to representatives of the family Cucurbitaceae. In contrast the experiments of Corbaz (1993) showed that one of the cucurbit powdery mildews (Sphaerotheca fuliginea, now Podosphaera xanthii) was not able to infect tomato. Similar results were published by Lebeda and Mieslerová (1999), who described unsucessful attempts to transfer Erysiphe cichoracearum (now Golovinomyces cichoracearum) and Podosphaera xanthii to tomato. On the other hand, Whipps and Helyer (1994) successfully transferred a powdery mildew Oidium spp., which occurred on eggplant (Solanum melongena) on tomato and tobacco, and in some degree also on cucumber (Cucumis sativus). These findings agree with the previous information of Fletcher et al. (1988), that powdery mildew from tomato can infect eggplant and tobacco. This information clearly referred to the great variability of isolates of $O$. neolycopersici and that the host range of $O$. neolycopersici was widley distributed since the isolates are able to infect the representatives of taxonomically distant groups.

Wild Solanum and Lycopersicon germplasm as sources of resistance

Extensive screening of tomato cultivars, excluding the study of wild relatives of tomato (Solanum spp.), showed that in the range of tomato cultivars (Solanum lycopersicum) available up to the end of 20th century, no effective sources of resistance to $O$. neolycopersici were found. Therefore breeders and phytopathologist turned their attention to wild relatives of tomato (Lindhout et al. 1994a; Mieslerová and Lebeda 1999).

Among the most important sources of resistance in the former genus Lycopersicon (now Solanum) are some genotypes of $S$. habrochaites (L. hirsutum), $S$. parviflorum (L. parviflorum), S. peruvianum (L. peruvianum) and S. pennellii (L. pennellii) (Lindhout et al. 1994a; Ignatova et al. 1997; Milotay and Dormanns-Simon 1997; Ciccarese et al. 1998; Mieslerová et al. 2000; Matsuda et al. 2005). In contrast within the species $S$. lycopersicon (L. esculentum) and $S$. pimpinellifolium (L. pimpinellifolium), which are the closest relatives of cultivated tomatoes, there were found only a few resistant genotypes (Georgiev and Angelov 1993; Kumar et al. 1995; Ciccarese et al. 1998; Mieslerová et al. 2000) and most of the closest relatives are highly susceptible to infection of powdery mildew.
Searching for resistance sources and their utilization in resistance breeding has resulted in the introduction of tomato lines with resistance to $O$. neolycopersici (e.g. NIL lines; Bai et al. 2005) or resistant cultivars (e.g. cv. "Grace"; Kashimoto et al. (2003b)). Afterwards racespecificity of the interactions in this pathosystem was confirmed when different isolates of $O$. neolycopersici overcame the resistance of these lines (Lebeda and Mieslerová 2002; Bai et al. 2005).

Variation in plant-pathogen interactions

\section{Non-host resistance}

The specificity of plant responses to pathogens can be classified into two broad categories, i.e. basic incompatibility (non-host-non-pathogen interaction) and basic compatibility (host-pathogen interaction). The phenomenon of non-host resistance is the most common form of disease resistance exhibited by plants against the majority of potentially pathogenic microorganisms and confers durable protection (Lebeda 1984; Heath 2000a; Niks and Marcel 2009). Several components of non-host resistance have been identified. Type I non-host resistance does not produce any visible symptoms, whereas type II non-host resistance results in a rapid hypersensitive response with cell death. Some similarities were hypothetised between nonhost and gene-for-gene resistance responses but it is still not clear if the same mechanism is involved (Mysore and Ryu 2004). Currently, more is known about the mechanisms of non-host resistance than about its genetics (Atienza et al. 2004; Niks and Marcel 2009; Ridout 2009).

Interactions between non-host and host plants and O. neolycopersici were studied in detail (Huang et al. 1997, 1998, 2000a; Lebeda and Mieslerová 1999, 2000; Lebeda et al. 2002; Mieslerová et al. 2004) from the viewpoint of histology, cytology and biochemistry. However, the phenomenon of non-host resistance is not very well understood. Huang et al. (1997, 1998) postulated that resistance in tomato and non-host species to $O$. neolycopersici is not primarily based on inhibition of spore germination. The second stage plant-pathogen interaction is represented by colonisation of plant tissue, including cell responses. Experiments by Mieslerová et al. (2004) showed that $O$. neolycopersici stopped its development on non-host plants (Lactuca sativa and Pisum sativum) early after the first 
appressoria and haustoria formed in plant cells. Huang et al. (2000a) observed intensive cell necrosis (hypersensitivity) in lettuce after inoculation with $O$. neolycopersici, which was in contrast with the observations of Mieslerová et al. (2004). In the interaction of Lactuca spp. and Bremia lactucae, a non-host resistance was not primarily associated with HR (Lebeda et al. 2001a, b, 2006). Also for the interaction between non-host plants and $O$. neolycopersici, it was concluded (Huang et al. 2000a) that resistance was not based on inhibition of formation of primary haustorium, but on post-haustorial HR and another type of nonhypersensitive resistance. This was confirmed by Mieslerová et al. (2004) who found no effective prehaustorial resistance. For a better understanding of this phenomenon we need a more detailed study of its biochemical and molecular background.

\section{Host resistance}

In contrast to non-host resistance, host plant disease resistance appears to be governed by a single gene or a small number of related genes, which encode proteins capable of altering the outcome of an otherwise compatible plant-pathogen interaction. Two basic types of host plant resistances can be distinguished: racespecific type and race-nonspecific (Crute and Pink 1996). The majority of genes catalogued for resistance to oomycetes, powdery mildews, rusts, smuts and bunts and several other facultative parasites appear to be race-specific (Crute and Pink 1996) and follow the gene-for-gene concept (Flor 1956). Race-specific resistance to rust and mildew is very often short lived, often lasting for an average of about five years when deployed. Race-specificity is indicative of a gene-forgene relationship, where specifically matching gene pairs determine infection outcomes (expressed as host resistance or susceptibility, and avirulence or virulence of the pathogen) for a given 'host genotype-pathogen genotype' interaction (Crute and Pink 1996). Racenonspecific resistance operate against all pathotypes or races of a pathogen. The genetic nature of this type of resistance is usually complex and based on the additive interaction of several genes having minor to intermediate effects. The development of DNA-based markers enabled analysis of the relationship between marker genotypes and variation in trait phenotypes to reveal quantitative traits into quantitative trait loci (QTLs) (Doerge 2002). These results could be the practical basis for breeding of plant varieties with resistance against powdery mildews (Ridout 2009).

Both possibilities, i.e. race-specific resistance and race-nonspecific resistance, including some other types of host resistance were confirmed in the interactions between Solanum (Lycopersicon) spp. and $O$. neolycopersici (Mieslerová et al. 2004). The virulence study of four isolates of $O$. neolycopersici originating from Czech Republic, Germany, the Netherlands and U.K. gave a clear and reproducible race-specific response on a set of 35 accessions of wild Solanum spp. From the reaction patterns with specific pathogen isolates, a preliminary differential set of Solanum spp. accessions and the existence of three races (OL1, OL2 and OL3) was proposed (Lebeda and Mieslerová 2000, 2002).

On the basis of detailed genetical research, five dominant $\mathrm{Ol}$ genes (Ol-1 and $\mathrm{Ol}-3, \mathrm{Ol}-4, \mathrm{Ol}-5$, Ol-6) and one recessive gene (ol-2) were described, and a unique set of near-isogenic lines (NILs) that harbour an introgression carrying the particular $\mathrm{Ol}$ gene in the genetic background of Solanum lycopersicum cv. Moneymaker (MM) have been generated (Bai et al. 2005, 2008; Seifi et al. 2011). With the NILs, it was further demonstrated that HR and papilla formation are associated with the resistance conferred by dominant and recessive $O l$ genes, respectively (Li et al. 2012).

In addition to monogenic $\mathrm{Ol}$ resistance genes, three QTLs in S. neorickii G1.1601 have been identified. The Ol-qtl1 interval overlaps with $\mathrm{Ol-1,O}$ Ol-3 and Ol-5 on chromosome 6, whereas the other two linked Ol-qtls are located on chromosome 12 in the vicinity of the $L v$ locus that confers resistance to another powdery mildew species, Leveillula taurica (Bai et al. 2003). Thus, the interaction of tomato with $O$. neolycopersici represent a pathosystem in which molecular mechanisms underlying monogenic and polygenic resistances can be compared directly (Li et al. 2012). Recent results showed that the three $\mathrm{Ol}$-qtls jointly confer a very high level of broad-spectrum resistance and that the resistance is associated with both the hypersensitive response and papillae formation, with the hypersensitive response being prevalent (Li et al. 2012).

\section{Adult plant resistance}

Powdery mildew resistance that retards infection and also growth and reproduction of the pathogen in adult 
plants but not in seedlings has been described as "adult plant resistance" (APR) (Gustafson and Shaner 1982) or "slow mildewing" (Shaner 1973). This type of resistance can be identified in cultivars with defeated racespecific resistance genes or without any known racespecific resistance genes. The phenomenon of adult plant resistance is known mainly in cereals-powdery mildew interactions (Carver and Adaigbe 1990; Heitefuss et al. 1997).

In Lycopersicon spp. adult plant resistance has been known for some time. It was observed by Huang et al. (1998) that the level of resistance to O. neolycopersici could depend on the tomato developmental stage. Detailed experiments with tomato confirmed the existence of adult resistance; whereas young plants (ca three weeks old) of line OR 4061 (Rijk Zwaan, the Netherland) were susceptible to O. neolycopersici, four month old plants appeared to be completely resistant (Mieslerová et al. 2004). At a cytological level Huang et al. (1998) found differences which depended on plant developmental stage. The frequency of epidermal cell necrosis was also lower in seedlings than in older hybrid plants (L. esculentum $\times$ L. hirsutum). However, the mechanisms responsible for this phenomenon and the timing of its activation are not known (Mieslerová et al. 2004).

\section{Field resistance}

One of the most important aspects of host-pathogen interactions is the study of the disease dynamics in host populations. This is related to the development of understanding of the epidemiology of plant pathogens (Zadoks and Schein 1979), as well as specific mechanisms of resistance. During the last three decades phytopathologists and breeders have become greatly interested in the phenomenon of field resistance (Parlevliet 1979). Field resistance is a phenomenon characterizing interactions of host and pathogen populations during the growing period, or its ontogenesis within a given agroecosystem. Field resistance is characterized by its quantitative character and its variability in time and space (Lebeda and Jendrulek 1988). For the study of field resistance, the methods of comparative epidemiology are of great importance (Kranz 2003).

The phenomenon of field resistance is little known in the interaction between wild Solanum spp. and tomato with $O$. neolycopersici. Glasshouse infection experiments with 10 Solanum accessions (Mieslerová and Lebeda, unpubl. results) showed significant differences in the disease progress during the growing period (ca 4-month) and the level of field resistance to $O$. neolycopersici (Table 2). The plants were planted in randomized complete block design with spreader rows of the artificially inoculated highly susceptible tomato cv. Amateur acting as sources of natural inoculum. The first disease symptoms were recorded on the 14th day after inoculation on the highly susceptible cv. Amateur, and to a lesser extent on both OR (Oidium resistant) tomato lines and $S$. peruvianum (LA 445). At the end of experiment (110th day after inoculation of spreader plants) susceptible tomato cv. Amateur was heavily infested. However, some other accessions (S. pennellii/LA 2560/, S. peruvianum/LA 445/, tomato line OR 4061) did not exceed $20 \%$ of the maximum infection degree (ID) (calculated using the Towsend and Heuberger (1943) formula) and expressed a slower rate of diseases development, i.e. a high level of field resistance. Another five Solanum spp. accessions did not show any disease symptoms (Table 2). These data suggest the existence of field resistance in Solanum spp., which it is not possible to reveal in laboratory experiments.

Mechanisms of Solanum spp. resistance

Infection cycle of O. neolycopersici

Some detailed studies of the infection cycle of $O$. neolycopersici on tomato and wild Solanum spp. have been carried out (Huang et al. 1998; Jones et al. 2000; Lebeda and Mieslerová 2000; Lebeda et al. 2002; Mieslerová et al. 2004). All authors agree that early after inoculation germination was observed starting between 3 and $6 \mathrm{~h}$ post inoculation (hpi) (Lebeda et al. 2002; Mieslerová et al. 2004); or before 17 hpi (Huang et al. 1998). Jones et al. (2000) described deposits of extracellular matrix (ECM) material that lie beneath the $O$. neolycopersici germ tubes, hyphae, around the margins of the appressorium and surrounding the O-ring at the site of host penetration, but not beneath ungerminated spores. The presence of ECM seems to be pivotal for successful adhesion, as the appressorial stage tissue remained attached to the host, whilst ungerminated conidia did not (Jones et al. 2000). The spore produced a primary short germ tube, ending in a primary appressorium, from which a primary haustorium was formed (Huang et al. 1998). The 
Table 2 Differences in field resistance of Solanum spp. accessions to $O$. neolycopersici (expressed as $\Sigma$ percentage of maximum infection degree (\%maxID)) and (area below infection curve $(\mathrm{ABC})$ ) (Mieslerová and Lebeda, unpubl.) a, b, c Scheffe's multiple comparison test $(P<0.05)$

\begin{tabular}{|c|c|c|c|}
\hline Solanum spp. accession & $\begin{array}{l}\Sigma \% \text { maxID } \\
\text { (leaf discs } \\
\text { experiments) }\end{array}$ & $\begin{array}{l}\Sigma \% \text { maxID } \\
\text { (field } \\
\text { experiments) }\end{array}$ & $\mathrm{ABC}$ \\
\hline S. lycopersicum cv. Amateur & 100 & $60.55^{\mathrm{a}}$ & 5918.75 \\
\hline S. lycopersicum OR 4061 & 10 & $13.33^{\mathrm{bc}}$ & 1328.00 \\
\hline S. lycopersicum OR 960008 & 55 & $28.88^{\mathrm{b}}$ & 2685.00 \\
\hline S. chmielewskii LA 2663 & 36.66 & $0^{\mathrm{c}}$ & 0 \\
\hline S. habrochaites LA 1347 & 28.33 & $0^{\mathrm{c}}$ & 0 \\
\hline S. habrochaites LA 1738 & 3.33 & $0^{\mathrm{c}}$ & 0 \\
\hline S. habrochaites f. glabratum LA2128 & 3.33 & $0^{\mathrm{c}}$ & 0 \\
\hline S. neorickii LA 1322 & 0 & $0^{\mathrm{c}}$ & 0 \\
\hline S. pennellii LA 2560 & 6.66 & $14.44^{\mathrm{bc}}$ & 1440.00 \\
\hline S. peruvianum LA 445 & 63.33 & $15.27^{b c}$ & 1493.75 \\
\hline
\end{tabular}

small peak in cutinase activity at the time of penetration and the appearance of the smooth-edged penetration hole suggest that this enzyme may play a role in penetration (Jones et al. 2000). Very often a secondary germ tube (colony forming hypha) arose from another tip of the spore which formed small opposite or spread, lobed-shaped (secondary) appressoria from which secondary haustoria arose (till $24 \mathrm{hpi}$ ). Later, third and fourth germ tubes (colony forming hyphae) emerging from the remaining poles of the spore also appeared (Mieslerová et al. 2004; Mieslerova and Lebeda 2010). Then all hyphae branched to form dense mycelial coat (Fig. 3). The time of observing the first appearance of conidiophores differs among authors. Huang et al. (1998) stated that at 89 hpi the first conidiophores were observed. However, Mieslerová et al. (2004) concluded that up to 72 hpi no conidiophores were observed, and intensive conidiation was detected $120 \mathrm{hpi}$.

Variation in development of primary infection structures

\section{Germination rate and germ tube formation}

After $6 \mathrm{~h}$ of incubation considerable differences were observed in the germination rate of $O$. neolycopersici on various plant lines (Mieslerová et al. 2004; Mieslerová and Lebeda 2010). At this time, a particularly low germination was evident on plants with hairy leaf surfaces. However, conidial germination was relatively high (61-97\%) on all plant lines after $48 \mathrm{~h}$ incubation. Huang et al. (1998) also recorded that spore germination in some Solanum accessions varied considerably between blocks so that the percentage of germination was not significantly different between resistant accessions and the susceptible control and among resistant accessions. Thus, spore germination does not appear to be affected by resistant accessions, indicating that resistance became effective only after spore germination and the process of penetration (Huang et al. 1998; Lebeda et al. 2002; Mieslerová et al. 2004).

Significant differences in the length of the first germ tube were recorded at 6 hpi (Mieslerová et al. 2004; Mieslerová and Lebeda 2010). At 24 hpi significant differences were found in all measured traits (length of the first germ tube and colony forming hyphae (2nd and 3rd), mean length of the hyphae). At 48 hpi the germs tubes and colony forming hyphae of $O$. neolycopersici were greatly elongated on highly susceptible accessions (Figs. 3 and 4). There were significant differences both in the length of germ tubes and colony forming hyphae and in the number of hyphae per conidia of $O$. neolycopersici between resistant and susceptible host lines. Also Huang et al. (1998) described significant reduction in the fungal growth components (number of hyphae per conidium, secondary appressoria per conidium and per hypha) in resistant Lycopersicon spp. accessions.

An interesting study was made by Nonomura et al. (2009), who obtained the exudates from trichomes of $S$. pennellii (earlier L. pennellii) and by inoculation tests found antifungal activity of these exudates against $O$. neolycopersici. The detected mechanism is complete inhibition of conidia germination. In leaves which were not sprayed with exudates from trichomes, 
Fig. 4 Schematic representation of Oidium neolycopersici development at 8, 24 and 72 hpi on leaf discs of susceptible genotype Solanum lycopersicum cv. Amateur. (according to Mieslerová and Lebeda 2010)

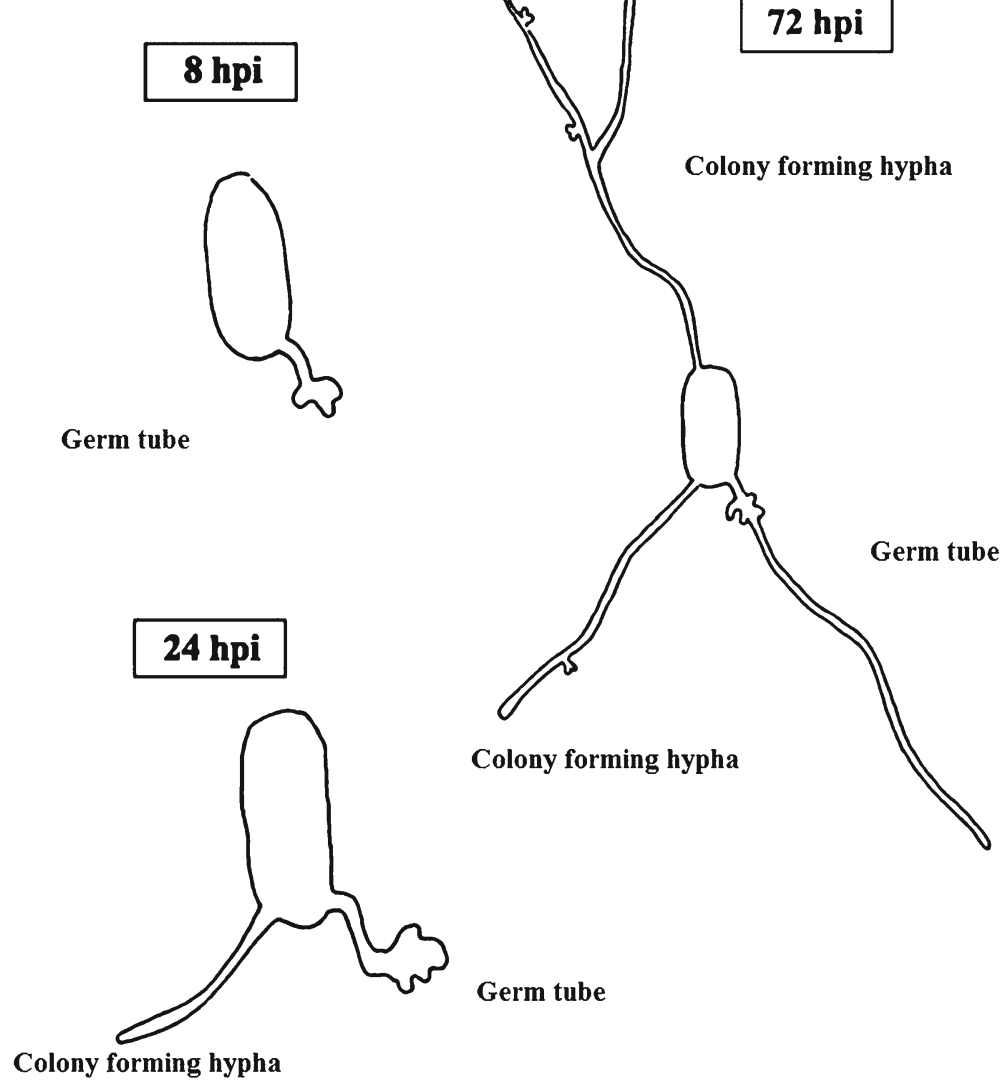

normal germination and development of appressoria and haustoria were recorded. The studied genotype of $S$. pennellii is commonly considered as susceptible to infection of $O$. neolycopersici and this mechanism considerably improved the ability to resist infection by $O$. neolycopersici (Nonomura et al. 2009).

\section{Appressoria and haustoria formation}

The first detailed study of appressoria formation showed that even at 6 hpi there were significant differences both in number of appressorium formed per germ tube and in the length of the first germ tube on resistant and susceptible accessions (Mieslerová et al. 2004). On all tested plant species, $O$. neolycopersici conidia started to germinate and produce typically lobed appressoria (Fig. 4).

A study on the shape of appressoria of $O$. neolycopersici was carried out by Nonomura et al. (2010). These authors studied in detail the initial stages of pathogen development and found that the original shape of appressoria of $O$. neolycopersici was rather simple, non-lobed, nippleshaped, and that the formation of a lobed appressorium came after unsuccessful attempts at penetration. Appressoria of conidia, which were immediately successful in penetration, were simple; however, after some unsuccessful atempts they became multilobed. This shape was also observed in conidia which germinated on resistant genotypes of wild tomatoes (L. peruvianum, recently $S$. peruvianum) or on a non-host plant (barley) (Nonomura et al. 2010).

Follow-up research (Takikawa et al. 2011) was focused on the study of germination of conidia of $O$. neolycopersici on various surface types, including tomato leaves, parafilm membrane, and agar. The aim was to reveal if the place on conidia, where germ tube arise, is affected by environment or is predetermined. It was found that germ tubes were always grown from the subterminal end of the conidium without any relation to place of the first contact of conidia with the sub- 
base. This study also confirmed that conidia of $O$. neolycopersici formed the germ tubes at a predetermined place (Takikawa et al. 2011).

Huang et al. (1998) reported that at 41 hpi and 65 hpi at least $70 \%$ of the infection units had formed a primary haustorium. There was no significant difference in the frequency of primary haustorium formation between resistant and susceptible accessions of Lycopersicon spp. (recently Solanum spp.), indicating that expression of resistance to fungal infection did not take place before primary haustorium formation.

\section{Epidermal cell reaction}

Generally, in the interaction of powdery mildews with their host plants, the crucial epidermal defence mechanism is considered to be a hypersensitive response and papilla formation (Aist and Bushnell 1991; Morel and Dangl 1997). The hypersensitive response is defined as a rapid necrosis of the plant cell in response to invasion by a pathogen (Wright and Heale 1988; Heath 2000b). This phenomenon is mostly connected with the formation of haustorium and might be restricted to only one cell, which the pathogen penetrated. The papilla is a type of thickening of the cell wall, which contains phenolics, callosis, silicon and toxic compounds, which encompass the place of penetration and strangulates the penetration peg and germ tube (Aist and Bushnell 1991; Carver et al. 1991; Kunoh 1995).

\section{Hypersensitive response}

The first reactions which were observed in resistant tomato plants were related to macroscopical symptoms. Lindhout et al. (1994a) macroscopically recorded that resistance in representatives of Solanum sect. Lycopersicon (early Lycopersicon) to $O$. neolycopersici is characterized by very limited growth of mycelium and by limitation or complete absence of sporulation. Both Huang et al. (1998) and Mieslerová et al. (2004) reported that in resistant Solanum (sect. Lycopersicon) accessions, many epidermal cells, in which a primary haustorium was formed, became necrotic, indicating a hypersensitive response (HR; Fig. 5). HR was observed much more frequently in all resistant accessions than in a susceptible control, and the level of hypersensitivity differed among resistant accessions. It was stressed that this type of defence response is not effective in all cases, and in some cases

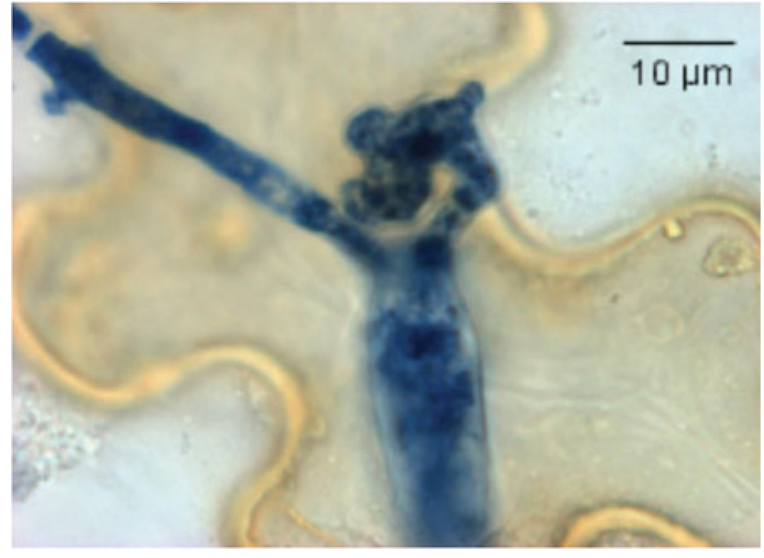

Fig. 5 Hypersensitive (necrotic) response of S. habrochites (previously $L$. hirsutum) after inoculation with $O$. neolycopersici. (photo B. Mieslerová)

continuous development of mycelium was detected, although penetrated cells showed necrotic responses (Mieslerová et al. 2004). This detailed study also confirmed the existence of other types of defence responses, characterized by marked constraint of mycelium development with complete absence of sporulation, indeed the frequency of occurrence of a hypersensitive response is low (Mieslerová et al. 2004).

\section{Papillae formation}

Papillae formation as a defence mechanism is common in cereals against powdery mildew (Aist and Bushnell 1991) and also in non-host resistance. In interactions of $O$. neolycopersici (host/non-host species), papillae formation was not considered as the frequent and effective resistance mechanism, however, papillae formation appeared in L. pennellii and Pisum sativum. This fact is in agreement with observations of Huang et al. (1998), who recorded papillae beneath some appressoria at very low frequencies in all accessions including the susceptible control. On average only 0 $9 \%$ of the appressoria induced papillae. Haustoria were present in at least $50 \%$ of the cells where papilla were induced. Therefore, papilla formation seems not to be an effective or a common mechanism of Solanum spp. resistance to $O$. neolycopersici.

\section{Callose accumulation}

The phenomenon of callose deposition at the sites of pathogen penetration was described in the muskmelon 
(Cucumis melo) - powdery mildew (Sphaerotheca fuliginea) pathosystem (Cohen et al. 1990). The authors described that the penetration zones were surrounded by a callose-like material, but no autofluorescence nor lignin-like materials were observed in the penetrated epidermal cells. Electron microscopical studies revealed that the rapid collapse of epidermal cells in the resistant cultivars was accompanied by the accumulation of callose-like deposits in cell walls and around haustoria. Occasionally, callose also appeared in epidermal and mesophyll cells adjacent to the penetrated cells.

Experiments carried out by Li et al. (2007) found that production of $\mathrm{H}_{2} \mathrm{O}_{2}$ and accumulation of callose are linked to the resistance determined by genes $\mathrm{Ol}-1$ and $\mathrm{Ol}-4$, which is manifested by hypersensitive response and also linked with the resistance due to recessive gene $o l-2$, which is connected with papillae formation. At 41 hpi, callose deposition was associated with HR cells, while at earlier time-points, callose was present around the wall of non-HR cells indicating that callose deposition occurred before visible HR (Li et al. 2007).

Later, it was found that resistance given by Ol-qtls, which is considered as polygenic, shows a wide spectrum of expression of hypersensitive response and papillae formation, where HR prevail. The production of $\mathrm{H}_{2} \mathrm{O}_{2}$ and accumulation of callosis, observed with resistance determined by $\mathrm{Ol}-1$ dominant gene, also occurred in resistance based on Ol-qtls (Li et al. 2012).

\section{Lignification}

Another plant defence strategy is generally associated with an increased passive resistance of the cell wall, i.e. by an elevated rate of lignin deposition in cells at the infection site (Cohen et al. 1990). In our experiments no changes in the deposition of lignin were observed in diseased or healthy plants of wild Solanum spp. during the first 120 hpi (Tománková et al. 2006).

\section{Development of $\boldsymbol{O}$. neolycopersici reproduction structures and intensity of sporulation}

The phenomenon of sporulation intensity has also been studied (Huang et al. 1998; Mieslerová et al. 2004). The most abundant sporulation was observed on susceptible tomato cultivars. On some wild Lycopersicon accessions which showed hypersensitive response some sporulation was still observed. No sporulation was recorded on highly resistant Lycopersicon spp. accessions and on non-host plant species (e.g. Lactuca sativa, Pisum sativum). Huang et al. (1998) compared the intensity of sporulation on a set of accessions inoculated by two methods. They found that sporulation on the print-inoculated plants was considerably poorer in the resistant accessions than in the susceptible control. Slight sporulation was found on resistant Lycopersicon spp. On the other hand, sporulation on spray-inoculated plants was almost absent in all the resistant accessions.

The interesting process of microcyclic conidiogenesis (MC), defined as the production of conidia on a spore without any, or only a minimal, involvement of hyphal growth, was confirmed by Kiss et al. (2010). This process was firstly described in Oidium longipes; however, $O$. neolycopersici is among other species, in which this phenomenon was observed. The authors concluded that mycoparasite Ampelomyces quisqualis preferred conidiophores produced by microcyclic conidiogenesis, and it was obvious, that by this proces the reproductive cycle of A. quisqualis can be accelerated (Kiss et al. 2010).

The formation of $O$. neolycopersici conidia in pseudochains was also described (Oichi et al. 2006). They found, by using microscopical observations, that $O$. neolycopersici produces the conidia in psedochains in non-optimal conditions regarding the intensity of wind (about $0.1 \mathrm{~m} / \mathrm{s}$ ). In higher intensity of wind, pseudochains are not formed, and it was also confirmed that this proces does not relate to levels of humidity, as was expected.

Physiology and biochemistry of host-pathogen interaction

Involvement and activity of antioxidant enzymes in plant systems

One of the first responses of host cells after the initiation of the interaction between plant and pathogen is the increased production of reactive oxygen species (ROS) (Lebeda et al. 2001a; Torres et al. 2006). A clear relation between production of ROS and changes in activities of enzymes involved in their metabolism with induction of defence response by biotic stress (e.g. invasion of pathogen) as well as abiotic stress (e.g. heat-shock) has been confirmed (Baker and Orlandi 1995; Bolwell and Wojtaszek 1997; Gulen 
and Eris 2004). Peroxidases (POXs) represent one of the important groups of enzymes, which participate in the metabolism of ROS in plants (Fig. 6). POX catalyse oxidoreduction reactions of various substrates via $\mathrm{H}_{2} \mathrm{O}_{2}$; however, they are also known to be involved in ROS production under specific conditions (Hiraga et al. 2001). POX can contribute to resistance against pathogens in various pathosystems (Baysal et al. 2005), whereas localized production of $\mathrm{H}_{2} \mathrm{O}_{2}$ and superoxide radical belong among the first cytologically and histochemicaly detected responses of plant tissue on penetration of pathogen. ROS are apparently involved in the induction of hypersensitive response and they function also as signal molecules in programmed cell death (Lamb and Dixon 1997; Hückelhoven and Kogel 2003).

Nitric oxide (NO), the ubiquitous intra- and extracellular messenger, has a wide spectrum of regulatory functions in plant growth, ontogenesis and responses to various stress stimuli. The key role of NO as a signal molecule and in defence processes of plants was documented in the relationships of plants to wound reaction (Orozco-Cardenas and Ryan 2002) and interactions with viruses, bacteria, oomycetes (e.g. Sedlářová et al. 2011) and fungi (Tada et al. 2004; Prats et al. 2005; Piterková et al. 2009). NO is vital for initiation and development of a hypersensitive response in plants, modification of gene expression and synthesis of PR (pathogenesis related) proteins (Wendehenne et al. 2004; Zeier et al. 2004; Mur et al. 2006; Zaninotto et al. 2006).

Production of ROS in interaction with $O$. neolycopersici Biochemical studies focused on the production of ROS and peroxidase activity during infection of Oidium neolycopersici showed that the production of ROS and the activities of corresponding enzymes were related with the activation of defence
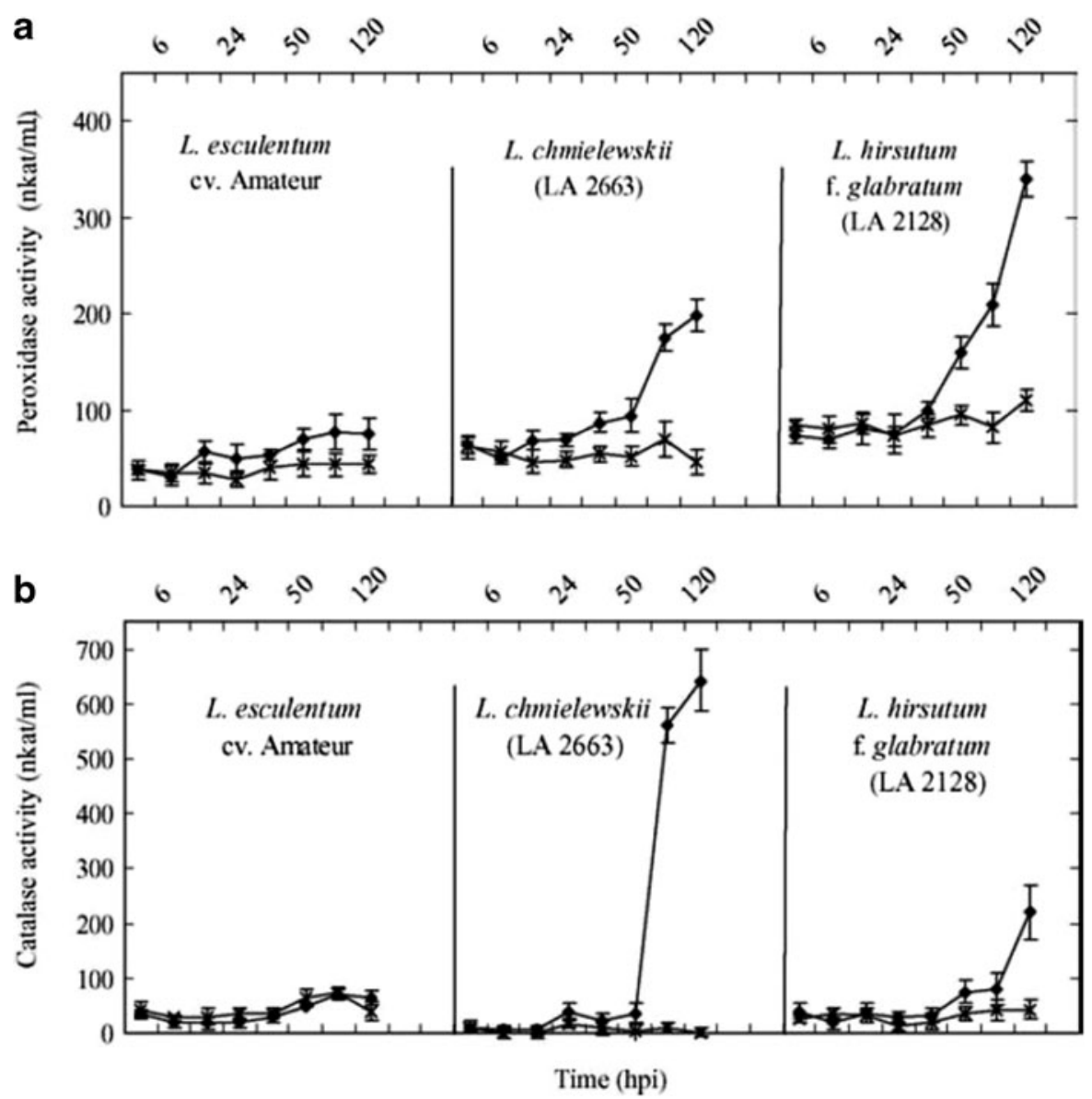

Fig. 6 Dynamics of POX (a) and catalase (b) activities after the inoculation of Lycopersicon spp. (recently Solanum spp.) accessions by O. neolycopersici. (black circle) Infected plants, (x) healthy plants (according to Mličková et al. 2004) 
responses in those genotypes of Solanum sect. Lycopersicon which showed certain level of resistance (S. habrochaites (earlier L. hirsutum) and $S$. chmielewskii (L. chmielewskii)). The most intensive production was detected in the genotypes which exhibit intensive hypersensitive responses. The timing of the highest activity of POX correlated with intensive production of $\mathrm{H}_{2} \mathrm{O}_{2}$ and the first expression of hypersensitive (necrotic) response (Mlíčková et al. 2004; Tománková et al. 2006; Figs. 5 and 6). Increased production of superoxide $\left(\mathrm{O}_{2}{ }^{-}\right)$was detected in a susceptible genotype S. lycopersicum (L. esculentum) during pathogenesis, however the production of $\mathrm{H}_{2} \mathrm{O}_{2}$ was not affected (Mlíčková et al. 2004). Catalase activity increased mainly in moderately resistant genotype $S$. chmielewskii (L. chmielewskii); the increased concentration of free phenols was recorded during the first $120 \mathrm{~h}$ post inoculation in all three genotypes ( $S$. lycopersicum, $S$. chmielewskii and S. habrochaites); but changes in lignification were not confirmed (Tománková et al. 2006).

Pei et al. (2011) investigated the role of another important enzyme, glutation S-transferase in the pathogenesis process, specifically the Ol-1-mediated resistance response. They used virus-induced gene silencing to knock-down expression of the putative GST gene (ShGST) in resistant tomato plants (Solanum habrochiates G1.1560, formerly L. hirsutum) carrying the Ol-1 gene. The ShGST-silenced plants showed a susceptible phenotype after inoculation with $O$. neolycopersici. Microscopic observation demonstrated that $O$. neolycopersici was able to complete its life cycle on silenced resistant plants; however silencing of ShGST did not completely abolish the HR and hydrogen peroxide $\left(\mathrm{H}_{2} \mathrm{O}_{2}\right)$ accumulation (Pei et al. 2011).

\section{Production of RNS}

\section{Local and systemic production of nitric oxide (NO)}

Experiments focused on production of ROS were followed by study of production of reactive nitrogen species (RNS), mainly NO and NO synthase-like enzyme involved in local and systemic defence responses (Piterková et al. 2009), using the same three genotypes of Solanum spp., which were used for the study of ROS production (Mlíčková et al. 2004). In the susceptible genotype $S$. lycopersicum (L. esculentum) cv. Amateur, elevated NO production was observed only during the early interval following inoculation, at 4-8 hpi.
Increased production of NO in two phases was observed in the highly and moderately resistant genotypes (S. habrochaites [L. hirsutum] and S. chmielewskii [L. chmielewskii]). Increasing NO production was also noticed as a systemic response in non-inoculated tissue elsewhere in the plant, which demonstrated the spreading of NO as a signal molecule within plant tissues after the pathogen attack. In resistant genotypes NO production was localized in host cells by confocal laser scanning microscope using NO-specific florescence probes. NO production was also confirmed in germinating conidia and germ tubes of powdery mildew, which points to a complex role of NO in the host-pathogen relationship (Piterková et al. 2009).

The role of nitric oxide (NO) as a signalling molecule involved in important signalling pathways has been demonstrated in many physiological and pathological processes among all living organisms from bacteria to man. The prototypical signalling function of NO includes the regulation of vascular tone upon its binding to the effector molecule, soluble guanylyl cyclase. Multiple targets of targets of NO have been identified among cytoplasmic and membrane proteins, membranes and transcription factors. Recently protein S-nitrosylation, based on reversible modification of cysteine thiol groups with NO-moiety, has emerged as one of most important protein post-translational modifications. The reversible protein (de)nitrosylation function as a reversible redox switch which can (de)active target proteins and thus regulate their activity in NO-dependent manner (Leitner et al. 2009, Mur et al.; Wendehenne et al. 2004).

\section{External application of $\mathrm{NO}$ modulators}

The same group carried out a detailed study on leaf discs of the same Solanum (Lycopersicon) spp. genotypes, where the main focus was placed on the germination and pathogen development in the presence of compounds modulating NO level (Piterková et al. 2011). The effect of the NO donor sodium nitroprusside varied among genotypes and over time whereas the NO scavenger 2phenyl-4,4,5,5,-tetramethylimidazoline-1-oxyl 3-oxide (cPTIO) accelerated the fungal development in all three Solanum spp. genotypes. The exposure of leaf discs to NOS (nitric oxide synthase) inhibitor $\mathrm{N}^{\mathrm{G}}$-nitro-L-arginine methyl ester decreased powdery mildew growth in S. chmielewskii. These results confirm an essential role for NO in powdery mildew pathogenesis including the 
penetration of a biotrophic pathogen and the initiation of a hypersensitive reaction, and suggest the contribution of NO to molecular mechanisms of diversity in interactions of Solanum spp. with O. neolycopersici.

\section{Production of NO in pathogen infection structures}

Nitric oxide production in physiological conditions has been observed by staining with DAF-FM DA (4-amino-5-(N-methylamino)-2',7'-difluorofluorescein diacetate) (Fig. 7). The specificity of this fluorescent probe has been widely discussed within the community of plant NO scientists. However, an alternative fluorophore, a pyrene-based cyclic o-quinodimethane named Fluorescent Nitric Oxide Cheletropic Trap (FNOCT) 8a, for direct detection of NO radical has been newly reported by Vandana et al. (2012), but is not available for general use yet. Thus the studies on NO role in $O$. neolycopersici development, performed in our laboratory during last few years, involved the DAF-FM DA-based histochemistry. In general, confocal laser scanning microscopy (CLSM) localized NO accumulation both in the powdery mildew infection structures as well as in the cells of infected leaves of resistant tomatoes. Signals for NO in germ tubes, appressoria and hyphae of $O$. neolycopersici, and in the penetrated cells of resistant wild tomatoes (S. chmielewskii and S. habrochaites) were reported by Piterková et al. (2009, 2011) 168 hpi and 72 hpi, respectively (Fig. 7).

The significance of NO in the tomato powdery mildew pathogenesis was supported by experiments with NO donors and scavengers. These were applied to leaf discs cut off the tomato leaves prior to inoculation and their trans-laminar effectors studied (Piterková et al. 2011). Although O. neolycopersici is a biotrophic pathogen, it is able to develop its early stages also on agar medium which was utilised for comparative microscopic studies (Sedlářová et al., unpublished). Both experiments with the exogenous application of compounds modulating NO metabolism, either on leaf discs or on agar, showed the necessity of this signalling molecule for $O$. neolycopersici germination and growth on agar media.

Involvement of JA, SA a ABA

Traditionally, salicylic acid (SA) was connected with defence signalling pathways expressed during plantbiotroph interactions and jasmonic acid (JA) during plant-necrotroph interactions, however, a cross-talk (situation where one or more components of one signal transduction pathway affect another) between these defence signalling pathways is presently intensively studied (Beckers and Spoel 2006; Thaler et al. 2012). Recently, the complex hormone cross-talk based on pathogen-induced hormonal changes that modulate disease and resistance in plants has been proposed. Additional hormones, namely abscisic acid (ABA), ethylene, auxins, cytokinins and brassinosteroids have also been implicated in the plant defence signalling network (Robert-Seilaniantz et al. 2011).

Changes in endogenous levels of three plant hormones (SA, JA, ABA) in Solanum spp. were analysed within 9 days following $O$. neolycopersici infection (Nožková-Hlaváčková et al., submitted). The effect of high temperature exposition $\left(2 \mathrm{~h}\right.$ at $\left.40.5^{\circ} \mathrm{C}\right)$ preceding inoculation was also studied in susceptible $S$. lycopersicum and moderately resistant $S$. chmielewskii. Concentration of hormones was compared with peroxidase activity and supplemented by the microscopic study of powdery mildew development. On susceptible $S$. lycopersicum the pathogen growth slightly accelerated after heat-shock. Concurrently, expression of chlorosis and necrosis intensified, linked to intensive accumulation of SA and JA (Fig. 8), and increased peroxidase activity. In moderately resistant $S$. chmielewskii, treatment by heat stress caused slight deceleration of pathogen development and increasing production of JA and $\mathrm{ABA}$ and increasing peroxidase activity in infected plants (Nožková-Hlaváčková et al., submitted).

A study concerning the effect of drought, salt stress and ABA on the resistance of tomato to $O$. neolycopersici showed that stress from affluence of salts significantly reduced infection by $O$. neolycopersici, however it did not produce any increase of endogenous ABA. Drought stress evoked a two-fold increase in concentration of endogenous $\mathrm{ABA}$ and markedly restricted development of $O$. neolycopersici on tomato (Achuo et al. 2006). In contrast, ABA-deficient mutant sitiens was more resistant to $O$. neolycopersici in comparison with the wild types. Exogenous application of ABA caused an increase in susceptibility of sitiens to the pathogen (Achuo et al. 2006).

As far as SA is concerned, Achuo et al. (2004) compared tomato plants that were unable to accumulate SA with their wild types and showed that SA was not involved in the basic defence mechanisms of tomato to $O$. neolycopersici. 

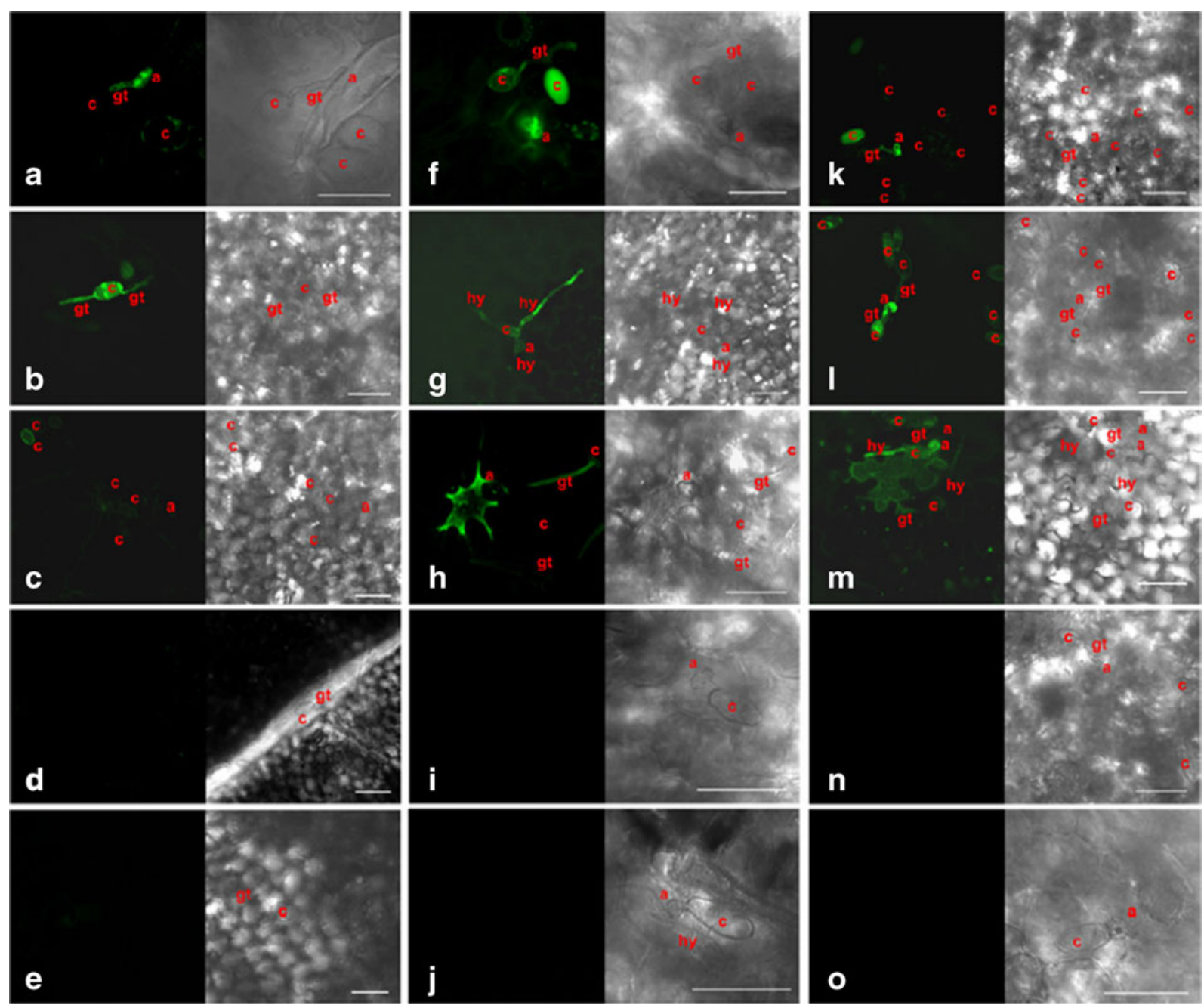

m
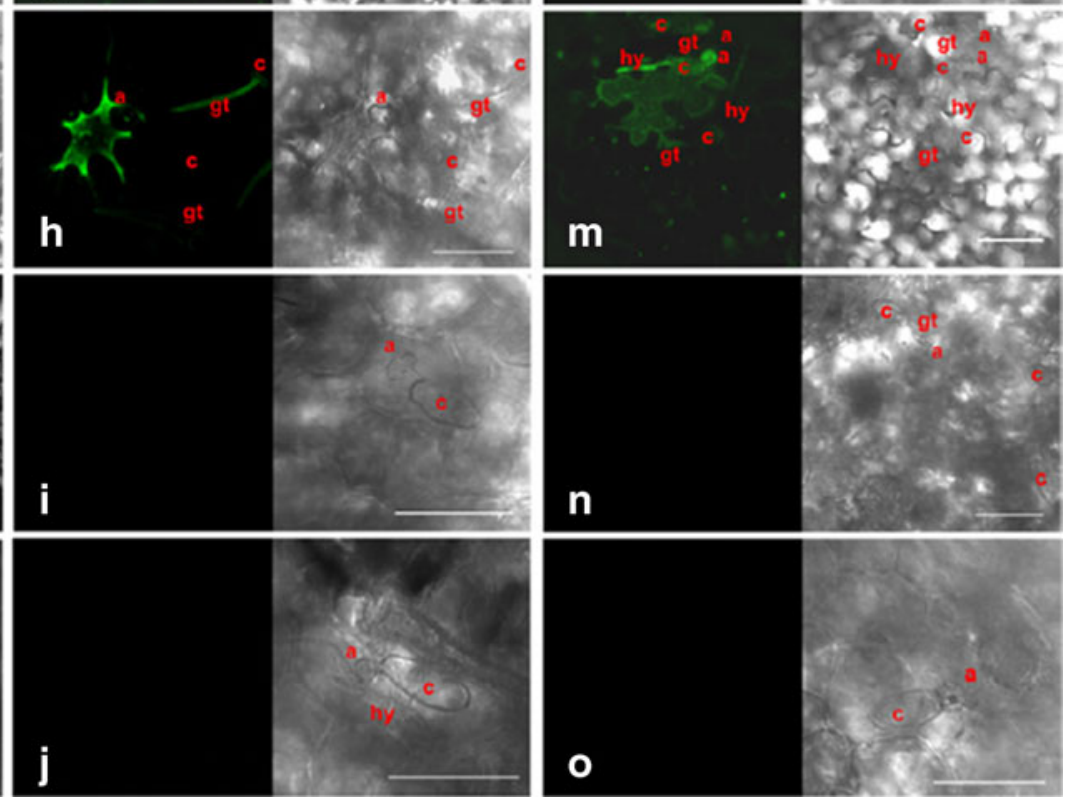

Fig. 7 Localization of NO production by confocal microscopy in Solanum spp.-Oidium neolycopersici interactions; S. lycopersicum (cv. Amateur) (a-e), S. chmielewskii (LA 2663) (f-j) and S. habrochaites f. glabratum (LA 2128) (k-o) at 24 hpi (a, d, e, f, i, j, k, n, o), 48 hpi (b, $\mathbf{g}, \mathbf{l})$ and $72 \mathrm{hpi}(\mathbf{c}, \mathbf{h}, \mathbf{m})$. Some leaf discs were pre-treated with NO

Signalling pathways of ROS, RNS and plant hormones and their interactions

ROS and RNS are crucial components of plant signalling pathways involved in the regulation of both physiological and developmental processes, and in the plant responses to stress stimuli including pathogen challenge (Wendehenne et al. 2004; Zaninotto et al. 2006). The cross-talk of signalling pathways of ROS and RNS and plant hormones has been widely characterized in important procesess like auxin-induced development of lateral roots or ABA-dependent regulation of stomatal closure.

scavenger cPTIO $(\mathbf{d}, \mathbf{i}, \mathbf{n})$ or NO synthase inhibitor L-NAME $(\mathbf{e}, \mathbf{j}, \mathbf{o})$ 30 min prior to the staining with DAF-FM DA probe. Pairs of photos represent confocal fluorescence and light differential interference contrast. Pathogen infection structures: c, conidium; gt, germ tube; a, appressorium; hy, hypha. Bar represents $50 \mu \mathrm{m}$. (photo M. Sedlářová)

Downstream effectors (second messengers which act downstream to activation of cell membrane receptors, whereas activators of cell membrane receptors act upstream of the production of second messengers) of ROSand RNS-dependent signalling include modification of ion channel permeability, changes in cytosolic calcium level and activation of MAP kinase cascades and transcription factors (Leitner et al. 2009; Mur et al. 2006). The interaction of ROS and RNS with cellular components results in a wide array of chemical modification which can strongly affect biological activities of the target molecules. Among them, S-nitrosylation 


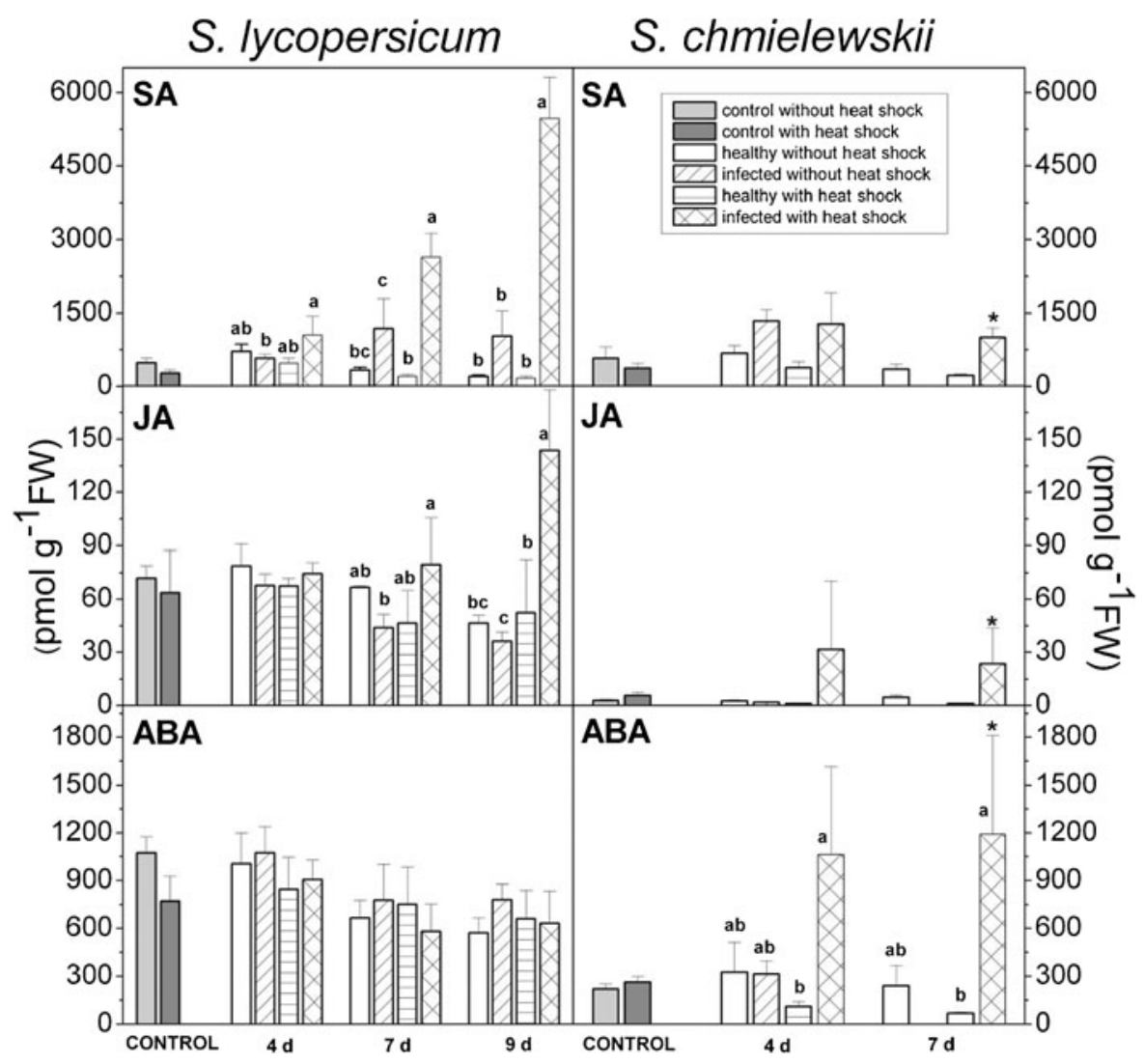

Fig. 8 Endogenous concentration of salicylic (SA), jasmonic (JA), and abscisic acid (ABA) in S. lycopersicum cv. Amateur, as well as $S$. chmielewskii 4,7 , and 9 days after inoculation by $O$. neolycopersici. Columns "control" designate healthy non-heatshocked plants that were measured 1 day before experiment

running, and which belong to the series of plants pre-treated or non-pre-treated by heat-shock. Means and SD are shown, $n=3$ $\left({ }^{*} n=2\right)$; statistically significant differences are indicated by different letters. Fw - fresh weighs, Missing data for S. chmielewskii are caused by abscission of leaves

of protein cystein thiols has now emerged as a key posttranslational modification of proteins within plant responses to pathogen infection. S-nitrosylation represents the convergence of signalling pathways of RNS and SA, as demonstrated by the role of S-nitrosylation in the activation of SA-binding proteins (Yu et al. 2012).

\section{Changes in photosynthesis of host plants}

In general, interactions with biotrophs are energy consuming either for the induction of plant defences or for competition of the pathogen for host nutrients. From this point of view photosynthesis plays a very important role in plant-pathogen interactions.

Plants infected with fungal biotrophic pathogens, including powdery mildew, exhibit a reduced rate of photosynthesis (Roberts and Walters 1988; Wright et al. 1995b; Sabri et al. 1997; Huang 2001; Akhkha et al. 2003). Powdery mildew can reduce host photosynthesis by various mechanisms, including reduction of assimilating leaf area (Moriondo et al. 2005), lower supply of light energy due to covering of the leaf surface by mycelium (Yurina et al. 1996) and inhibition of $\mathrm{CO}_{2}$ influx due to stomata closure (Gordon and Duniway 1982). Powdery mildew can also affect photosynthesis via changes in source-sink relations and nutrient remobilization towards infection sites (Scholes et al. 1994; Wright et al. 1995a; Abood and Lösel 2003). This can result in the inhibition of the Calvin cycle (Gordon and Duniway 1982; Scholes et al. 1994; Wright et al. 1995b) and in the inhibition of photosynthetic light reactions in thylakoid membranes (Magyarosy et al. 1976). It has been suggested that the down-regulation of photosynthesis during powdery mildew infection is caused by higher activity of a cell-wall invertase, which leads to the accumulation of hexose 
sugars (Scholes et al. 1994; Wright et al. 1995b; Swarbrick et al. 2006) and subsequently to feed-back inhibition of the expression of some photosynthetic genes (especially $c a b$ and $r b c S$ ) (Scholes et al. 1994; Fotopoulos et al. 2003; Swarbrick et al. 2006).

The study of photosynthetic response of tomato plants to $O$. neolycopersici in susceptible (S. lycopersicum cv. Amateur) and moderately resistant (S. chmielewskii) genotypes revealed only minimal impairment of photosynthesis in both genotypes during the first 9 days after inoculation (Prokopová et al. 2010). A slight decrease in $\mathrm{F}_{\mathrm{V}} / \mathrm{F}_{\mathrm{M}}$ parameter (maximal quantum yield of photosystem II photochemistry) and increase in nonphotochemical chlorophyll fluorescence quenching (NPQ) were observed (Fig. 9) indicating slightly reduced photosystem II photochemistry and slowed down Calvin cycle reactions, respectively. In the susceptible genotype more pronounced changes in photosynthesis were expected in the later stages of the infection (about 14 days after inoculation) when premature senescence of the infected leaves occurred, most probably due to the activation of the cell-wall invertase. Leaf shading by the mycelium and pathogen-induced stomatal closure could contribute to the assumed inhibition of photosynthesis, too (Prokopová et al. 2010). In the moderately resistant genotype (S. chmielewskii), the $\mathrm{F}_{\mathrm{V}} / \mathrm{F}_{\mathrm{M}}$ decrease and NPQ increase were probably associated mainly with HR and subsequent wilting and necrotization of the infected leaves (Prokopová et al. 2010). In summary the different degree of host resistance/susceptibility did not markedly change the rate and extent of the photosynthetic response to the pathogen, despite the different mechanisms involved in this response.

Influence of temperature and light on infection process and reproduction of $O$. neolycopersici

The influence of environmental conditions on development of different powdery mildews has been reported by various authors (e.g. Aust and Hoyningen-Huene 1986; Braun 1987; Jarvis et al. 2002; Kenyon et al. 2002). There is a general conclusion that the development of

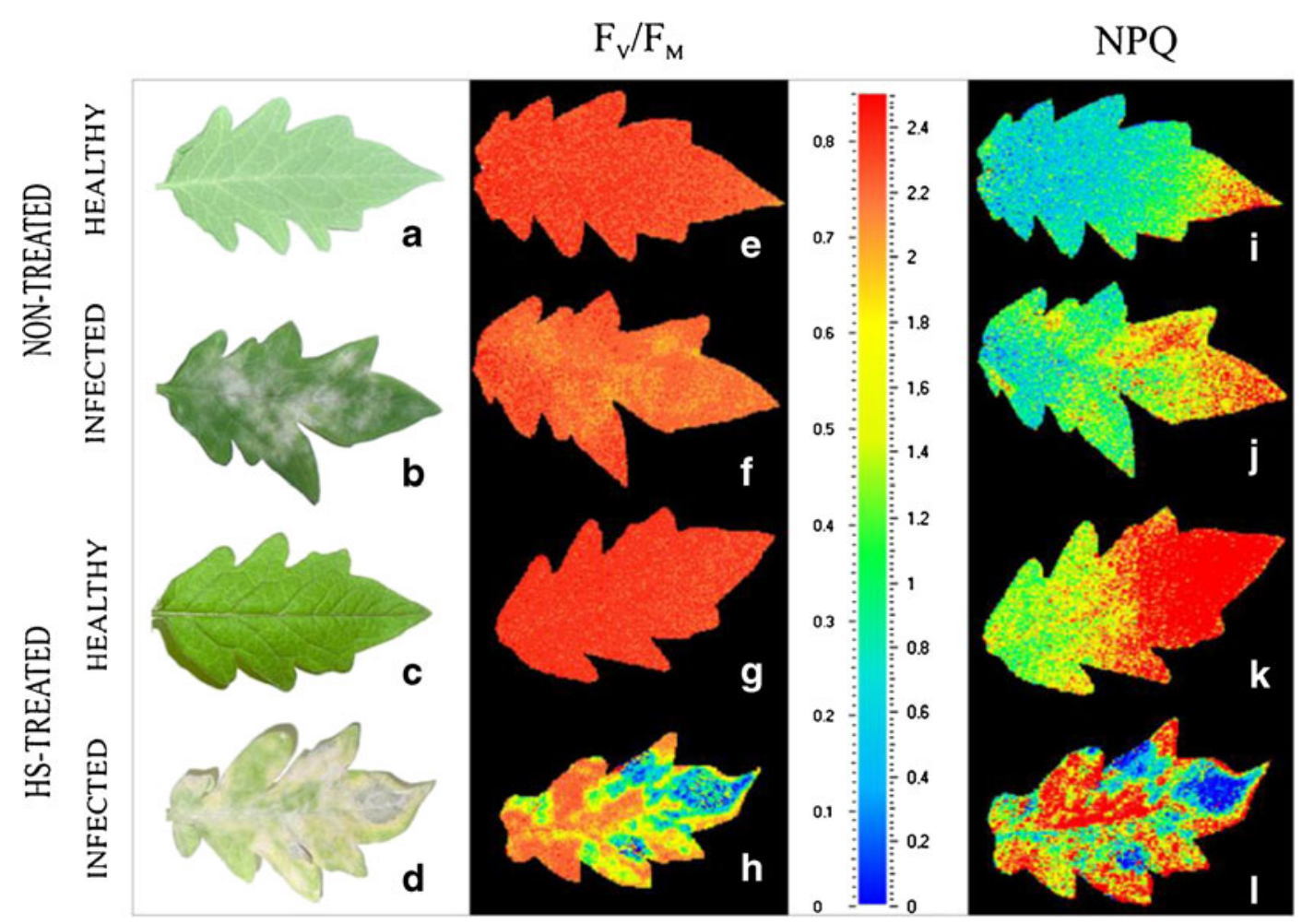

Fig. 9 Photographs (a-d) of representative healthy and powdery mildew (O. neolycopersici) infected leaflets of the susceptible tomato genotype, $S$. lycopersicum cv. Amateur, pre-treated or not pre-treated with heat-shock (HS; the image of maximal quantum yield of photosystem II photochemistry) $\left(\mathrm{F}_{\mathrm{V}} / \mathrm{F}_{\mathrm{M}} ; \mathbf{e}-\mathbf{h}\right)$ and steadystate value of non-photochemical fluorescence quenching (NPQ; i-l) in the same leaflets. All pictures taken 9 days after inoculation (Prokopová et al. 2010) 
powdery mildews is significantly affected by host genotype and by combinations of environmental variables, including temperature, relative humidity and light. The basic conditions important for development of $O$. neolycopersici have also been studied (Fletcher et al. 1988; Hannig 1996; Whipps and Budge 2000; Jacob et al. 2008; Mieslerová and Lebeda 2010).

The most suitable temperature for germination, development and conidia formation is considered to lie in the range $20-25{ }^{\circ} \mathrm{C}$ (Fletcher et al. 1988; Jacob et al. 2008). In a detailed study by Mieslerová and Lebeda (2010) it was found that conidia germinated across the whole range of the tested temperatures $\left(10-35{ }^{\circ} \mathrm{C}\right)$; however, at the extremes germination was strongly limited. At temperatures slightly lower than optimum $\left(20-25^{\circ} \mathrm{C}\right)$, mycelial development and time of appearance of the first conidiophores was delayed. Conidiation occurred within the range of $15-25^{\circ} \mathrm{C}$, however it was most intense between $20-25{ }^{\circ} \mathrm{C}$.

Pathogen development was also markedly influenced by light conditions (Jacob et al. 2008; Mieslerová and Lebeda 2010). Jacob et al. (2008) found that the highest rates of conidial germination were observed at a minimum light intensity, optimal conditions for appressoria formation were at $1750 \mathrm{~lx}$, and the greatest number of conidia was produced at the highest light intensity, 5150 1x. similar results were confirmed by Kashimoto et al. (2003a), who found, that optimal light conditions for development of a Japanese isolate of $O$. neolycopersici were 3,500 lx $\left(\sim 62.2 \mu \mathrm{mol} . \mathrm{m}^{-2} . \mathrm{s}^{-1}\right)$, while in their experiments this intensity was the maximal tested, and under lower light intensity the rate of pathogen development was limited.

Mieslerová and Lebeda (2010) postulated that conidiation and mycelium development was greatest at light intensities of approximately $60 \mu \mathrm{mol} . \mathrm{m}^{-2} . \mathrm{s}^{-1}$. At lower intensities, pathogen development was delayed, and in the dark, conidiation was completely inhibited. A dark period of $24 \mathrm{~h}$ after inoculation had no stimulatory effect on later mycelium development. However, $12 \mathrm{~h}$ of light after inoculation, followed by continuous dark, resulted in delayed mycelium development and total restriction of pathogen conidiation (evaluated 8 days postinoculation). When a longer dark period (4 days) was followed by normal photoperiod (12 h / $12 \mathrm{~h}$ light / dark), mycelium development accelerated and the pathogen sporulated normally. When only the inoculated leaf was covered with aluminium foil while the whole plant was placed in photoperiod $12 \mathrm{~h} / 12 \mathrm{~h}$, intensive mycelium development and slight subsequent sporulation on the covered leaf was recorded.

\section{Temperature-dependent resistance}

In many pathosystems it has been found that resistance or susceptibility can be influenced by temperature. Exposure to higher temperature can lead to induction of resistance or to increasing of susceptibility. Schweizer et al. (1995) and Vallélian-Bindschedler et al. (1998) stated that short exposition of susceptible cultivar of barley to high temperature $\left(30-60 \mathrm{~s}\right.$ at $\left.50^{\circ} \mathrm{C}\right)$ induced resistance and reduced following infection by powdery mildew (Blumeria graminis f.sp. hordei). However, in other pathosystems even an opposite effect has been demonstrated, i.e. increased susceptibility after application of higher temperature (Chamberlain and Gerdemann 1966; Chen et al. 2003).

These questions were studied in the pathosystem Solanum spp.-Oidium neolycopersici by our research team (Mieslerová et al. 2006; Prokopová et al. 2010; Nožková-Hlaváčková et al., submitted). In a detailed study whole plants were used, which were treated for $2 \mathrm{~h}$ before inoculation with temperature $40.5^{\circ} \mathrm{C}$, while control plants were placed under $20{ }^{\circ} \mathrm{C}$. The expression of resistance in $S$. chmielewskii was not markedly influenced macroscopically, while in S. lycopersicum there was an increase of necrosis and chlorosis (Prokopová et al. 2010) and the rate of $\mathrm{CO}_{2}$ assimilation and the $F_{V} / F_{M}$ ratio decreased in the infected leaves (Fig. 9). These changes could be associated with the mentioned cell-wall invertase activation amplified by an increased demand for carbohydrates in heat shockinduced defence reactions (Prokopová et al. 2010).

Generally, in this pathosystem under this specific treatment the heat-shock accelerated and intensified the development of symptoms and signs of attack, only in susceptible tomato genotype.

Resistance of tomato against $O$. neolycopersici as a highly complex and broadly orchestrated phenomenon

\section{Synthesis of recent knowledge}

The reduced genetic variation of cultivated tomato can in part explain the slow rate of tomato improvement that was achieved up to about 1940, when the first use 
of wild species as a source of desired traits was reported. Thereafter, there was an increase in the exploitation of the favourable attributes found in tomato wild species via interspecific crosses (Grandillo et al. 2011). Extensive germplasm resources and a vast amount of genetic variation in tomato wild relatives are the primary assets for tomato improvement. The wild Solanum sect. Lycopersicon (the clade containing the domesticated tomato and its 12 wild relative species) possess many traits of economic importance, including resistance to diseases and pests. All these attributes are potentially transferable to the cultivated tomato via conventional breeding as well as various other approaches needed to break the crossing barriers between some of these species (Ji and Scott 2007). Wild tomato species have been used as a source for major genes for disease and pest resistance, as shown by numerous resistance genes derived from these wild relatives, which can be found in modern cultivars (Grandillo et al. 2011). However, until now the wild Solanum sect. Lycopersicon species has been not widely exploited from the viewpoint of resistance to $O$. neolycopersici.

The numerous molecular studies conducted using interspecific Solanum spp. crosses have clearly demonstrated that the breeding value of wild germplasm goes much beyond its phenotype. However, in spite of these results, we are still far from having been able to fully exploit the resistance breeding potential of a huge amount of Solanum spp. accessions stored in gene banks (Grandillo et al. 2011). From the viewpoint of tomato resistance breeding to $O$. neolycopersici the species Solanum chmielewskii, S. habrochaites and $S$. neorickii could be considered as enormously valuable (Lebeda and Mieslerová 1999, 2000, 2002; Mieslerová et al. 2000).

In this review, we have shown that interactions between Solanum spp. and $O$. neolycopersici are extremelly variable. Resistance of wild Solanum spp. and tomato against $O$. neolycopersici is a highly complex phenomenon which is influenced by many external and internal factors. Understanding the cytology, physiology and biochemistry of powdery mildews and their interactions with the host plants can help us to improve disease management strategies and assist in the deployment of resistance genes (Ridout 2009).

Revealing the biochemical changes in plants during pathogenesis and comparison of the course of events between susceptible and resistant plants can help in the understanding of ways how plants defend themselves and how to apply this in plant breeding and protection (Li et al. 2006). Detailed investigations into the molecular mechanisms of resistance could eventually provide leads for the development of more durable disease resistance (Ridout 2009). For the better understanding of the whole cascade of processes occurring in attacked plants we need to interlink these studies with moleculargenetic study ( $\mathrm{Li}$ et al. 2006).

We know that the interaction between wild Solanum spp., tomato and $O$. neolycopersici is in many cases race-specific and governed by different race-specific genes (Ol-genes, Ol-1-Ol-6, or Ol-qtl 1-3) localized in different wild Solanum species (e.g. S. habrochaites, S. peruvianum, $S$. neorickii). Hypersensitive reaction is the most common resistance mechanism in these species (Huang et al. 1998; Lebeda et al. 2002; Mieslerová et al. 2004). However, a complicated cascade of physiological and biochemical processess underlies this cell event which represents a broadly orchestrated phenomenon.

It is evident that a complex of interactions of plant hormones, reactive oxygen (ROS) and nitrogen species (RNS) is involved in the regulation of multiple events both in plant and pathogen cells. The first phase of the pathogenesis process, starting with the contact of the pathogen with plant cells, is intimately connected with the activation of signalling pathways. This plantpathogen recognition event includes induction of ROS and RNS and other secondary messengers, and is in general observed both in susceptible and resistant Solanum genotypes. Beside that, ROS and RNS are also produced in pathogen cells and seem to be key factors in successful growth and development of pathogen structures. However, only resistant plants are capable of inducing the second-phase of biochemical responses, which range from the accumulation of ROS and RNS necessary for the initiation of plant cell death as a part of a hypersensitive response, to the strong activation of defence genes involved in the production of antioxidant enzymes and defence phytochemicals. As a result of the regulated production of defence biochemical compounds further growth of the pathogen and colonization of plant tissue is restricted on a local level. Moreover, in resistant Solanum genotypes the resistance on a systemic level is induced in distant plant tissues and organs, but an understanding of the exact mechanisms and biochemical signals responsible for the initiation of systemic resistance still remains elusive. 


\section{Future developments}

Since the publication of a previous review (Mieslerová and Lebeda 1999) we have gained extensive knowledge on the taxonomy and biology of $O$. neolycopersici, the variability of interactions between wild Solanum spp. and O. neolycopersici and its hosts, sources of resistance and resistance mechanisms, as well as on the application of this knowledge in tomato resistance breeding.

Further research is needed in following areas:

1) Sexual reproduction and strategies for overwintering of $O$. neolycopersici;

2) Host range of $O$. neolycopersici on cultivated and wild species of Solanaceae;

3) Intraspecific variability of the interactions between $O$. neolycopersici and its hosts aiming at the development of an internationally-accepted system for race determination and denomination;

4) Discovery of new effective sources of resistance, including their characterization and transfer to breeding materials; genetics of race-specific resistance/susceptibility;

5) Non-host and host resistance, their histological, cytological, physiological, biochemical and molecular mechanisms;

6) A better understanding of the whole cascade of processes, interlinking physiological and biochemical studies with molecular-genetic study;

7) Implementation of available genomic, transcriptomic and proteomic approached to further elucidate key factors associated with host sensitivity and resistance to $O$. neolycopersici;

8) Population biology and genetics of $O$. neolycopersici for understanding pathogenic variability, their dynamics in time and space;

9) Comparative epidemiology of $O$. neolycopersici and its migration between wild and crop plant pathosystems.

Acknowledgments This research was supported by grants MSM 6198959215, ME08048, LH11013 and GAČR P501/12/ 0590. M. S. and V. N.-H. were supported by the project Centre of the Region Haná for Biotechnological and Agricultural Research from the European Regional Developmental Fund (ED0007/01/01). Some isolates used in this study are maintained under National Programme of Genepool Conservation of Microorganisms and Small Animals of Economic Importance, funded by Ministry of Agriculture of the Czech Republic.

\section{References}

Abood, J. K., \& Lösel, D. M. (2003). Changes in carbohydrate composition of cucumber leavesduring the development of powdery mildew infection. Plant Pathology, 52, 256-265.

Achuo, E. A., Audenaert, K., Meziane, H., \& Hofte, M. (2004). The salicylic acid-dependent defence pathway is effective against different pathogens in tomato and tobacco. Plant Pathology, 53, 65-72.

Achuo, E. A., Prinsen, E., \& Hofte, M. (2006). Influence of drought, salt stress and abscisic acid on the resistance of tomato to Botrytis cinerea and Oidium neolycopersici. Plant Pathology, 55, 178-186.

Aist, J. R., \& Bushnell, W. R. (1991). Invasion of plants by powdery mildew fungi, and cellular mechanism of resistance. In G. T. Cole \& H. C. Hoch (Eds.), The fungal spore and disease initiation in plants and animals (pp. 321-346). New York and London: Plenum Press.

Akhkha, A., Clarke, D. D., \& Dominy, P. J. (2003). Relative tolerance of wild and cultivated barley to infection by Blumeria graminis f. sp. hordei (syn. Erysiphe graminis f. sp. hordei). II- the effects of infection on photosynthesis and respiration. Physiological and Molecular Plant Pathology, 62, 347-354.

Angelov, D., \& Georgiev, P. (1993). Identification of the new powdery mildew agent on tomatoes in Bulgaria. Proceedings of the XIIth EUCARPIA meeting on Tomato, Genetics and Breeding. Plovdiv, Bulgaria, 27-31 July 1993, pp. 51-54.

Arredondo, C. R., Davis, R. M., Rizzo, D. M., \& Stahmer, R. (1996). First report of powdery mildew of tomato in California caused by an Oidium sp. Plant Disease, 80, 1303.

Atienza, S. G., Katary, H., \& Niks, R. E. (2004). Accumulation of genes for susceptibility to rust fungi for which barley is nearly a non-host results in two barley lines with extreme multiple susceptibility. Planta, 220, 71-79.

Aust, H. J., \& Hoyningen-Huene, J. (1986). Microclimate in relation to epidemics of powdery mildew. Annal Review of Phytopathology, 24, 491-510.

Bai, Y. L., Huang, C. C., van der Hulst, R., Meijer-Dekens, F., Bonnema, G., \& Lindhout, P. (2003). QTLs for tomato powdery mildew resistance (Oidium lycopersici) in Lycopersicon parviflorum G1.1601 colocalize with two qualitative powdery mildew resistance genes. Molecular Plant Microbe Interactions, 16, 169-176.

Bai, Y., van der Hulst, R., Huang, C. C., Wei, L., Stam, P., \& Lindhout, P. (2004). Mapping Ol-4, a gene conferring resistance to Oidium neolycopersici and originating from Lycopersicon peruvianum LA2172, requires multi-allelic, single-locus markers. Theoretical and Applied Genetics, 109, 1215-1223.

Bai, Y., van der Hulst, R., Bonnema, G., Marcel, T. C., MeijerDeckens, F., Niks, R. E., \& Lindhout, P. (2005). Tomato defense to Oidium neolycopersici: Dominant $\mathrm{Ol}$ genes confer isolate-dependent resistance via a different mechanism than recesive ol-2. Molecular Plant Microbe Interactions, $18,354-362$.

Bai, Y., Pavan, S., Zheng, Z., Zappel, N. F., Reinstädler, A., Lotti, C., et al. (2008). Naturally occurring broad-spectrum powdery mildew resistance in a Central American tomato 
accession is caused by loss of mlo function. Molecular Plant-Microbe Interactions, 21, 30-39.

Baker, C. J., \& Orlandi, E. W. (1995). Reactive oxygen in plant pathogenesis. Annual Review of Phytopathology, 33, 299-321.

Baysal, O., Gursoy, Y., Ornek, H., \& Duru, A. (2005). Induction of oxidants in tomato leaves treated with DL-beta-amino butyric acid (BABA) and infected with Clavibacter michiganensis ssp. michiganensis. European Journal of Plant Pathology, 112, 361-369.

Beckers, G. J. M., \& Spoel, S. H. (2006). Fine-tuning plant defence signalling: Salicylate versus jasmonate. Plant Biology, 8, 1-10.

Blancard, D. (1992). A Colour Atlas of Tomato Diseases. London: Wolfe Publishing Ltd.

Blumer, S. (1967). Echte Mehltaupilze (Erysiphaceae). Jena, Germany: VEB Gustav Fischer Verlag.

Bolwell, G. P., \& Wojtaszek, P. (1997). Mechanisms for the generation of reactive oxygen species in plant defence-a broad perspective. Physiological and Molecular Plant Pathology, 51, 347-366.

Braun, U. (1987). The monograph of the Erysiphales (powdery mildews). Beihefte zur Nowa Hedwigia, 89, 1-700.

Braun, U. (1995). The powdery mildews (Erysiphales) of Europe. Jena: Gustav Fischer Verlag.

Braun, U. (1999). Some critical notes on the classification and generic concept of the Erysiphaceae. Schlechtendalia, 3, 49-55.

Braun, U., \& Cook, R. T. A. (2012). Taxonomic Manual of the Erysiphales (Powdery Mildews). Utrecht, The Netherlands: CBS-KNAW Fungal Biodiversity Centre. 707 pp.

Braun, U., \& Takamatsu, S. (2000). Phylogeny of Erysiphe, Microsphaera, Uncinula (Erysipheae) and Cystotheca, Podosphaera, Sphaerotheca (Cystotheceae) inferred from rDNA ITS sequences-some taxonomic consequences. Schlechtendalia, 4, 1-33.

Braun, U., Cook, R. T. A., Inman, A. J., \& Shin, H.-D. (2002). The taxonomy of the powdery mildew fungi. In R. R. Bélanger, W. R. Bushnell, A. J. Dik, \& T. L. W. Carver (Eds.), The Powdery Mildews. A Comprehensive Treatise (pp. 13-55). St Paul, MN, USA: APS Press.

Carver, T. L. W., \& Adaigbe, M. E. (1990). Effects of oat host genotype, leaf age and position and incubation humidity on germination and germling development by Erysiphe graminis f. sp. avenae. Mycological Research, 94, 18-26.

Carver, T. L. W., Robbins, M. P., \& Zeyen, R. J. (1991). Effect of two PAL inhibitors on the susceptibility and localized autofluorescent host cell responses of oat leaves attacked by Erysiphe graminis DC. Physiological and Molecular Plant Pathology, 39, 269-287.

Chamberlain, D. W., \& Gerdemann, J. W. (1966). Heat-induced susceptibility of soybeans to Phytophthora megasperma var. sojae, Phytophthora cactorum, and Helminthosporium sativum. Phytopathology, 56, 70-73.

Chen, Z. J., Ribeiro, A., Silva, M. C., Santos, P., GuerraGuimaraes, L., \& Gouveia, M. (2003). Heat shockinduced susceptibility of green coffee leaves and berries to Colletotrichum gloeosporioides and its association to PR and hsp70 gene expression. Physiological and Molecular Plant Pathology, 63, 181-190.

Child, A. (1990). A synopsis of Solanum subgenus Potatoe (G. Don) D’Arcy [Tuberarium (Dun.) Bitter (s.1.)]. Feddes Repertorium, 101, 209-235.
Ciccarese, F., Amenduni, M., Schiavone, D., \& Cirulli, M. (1998). Occurrence and inheritance of resistance to powdery mildew (Oidium lycopersici) in Lycopersicon species. Plant Pathology, 47, 417-419.

Cohen, Y., Eyal, H., \& Harania, J. (1990). Ultrastructure, autofluorescence, callose deposition and lignification in susceptible and resistant muskmelon leaves infected with the powdery mildew fungus Sphaerotheca fuliginea. Physiological and Molecular Plant Pathology, 36, 191-204.

Cooke, M. C., \& Massee, G. (1888). Australasian fungi. Grevillea, 16, 114.

Corbaz, R. (1993). Spread of a powdery mildew of the Cucurbitaceae (Erysiphe cichoracearum) to tomatoes. Revue Suisse de Viticulture, d'Arboriculture et d'Horticulture, 25, 389-391.

Crute, I. R., \& Pink, D. A. C. (1996). Genetics and utilization of pathogen resistance in plants. Plant Cell, 8, 1747-1755.

Dixon, G. R. (1981). Vegetable Crop Diseases. Westport, CT: AVI Publishing.

Doerge, R. W. (2002). Mapping and analysis of quantitative trait loci in experimental populations. Nature Reviews. Genetics, $3,43-52$.

Fletcher, J. T., Smewin, B. J., \& Cook, R. T. A. (1988). Tomato powdery mildew. Plant Pathology, 37, 594-598.

Flor, H. H. (1956). The complementary genetic systems in flax and flax rust. Advances in Genetics, 8, 29-54.

Fotopoulos, V., Gilbert, M. J., Pittman, J. K., Marvier, A. C., Buchanan, A. J., \& Sauer, N. (2003). The monosaccharide transporter gene, AtSTP4, and the cell-wall invertase, Atbfruct1, are induced in Arabidopsis during infection with the fungal biotroph Erysiphe cichoracearum. Plant Physiology, $132,821-829$.

Georgiev, P., \& Angelov, D. (1993). Reaction of different tomato varieties to powdery mildew causal agent Sphaerotheca fuliginea f. lycopersicum (Cooke \& Massee). Proceedings of the XIIth EUCARPIA Meeting on Tomato, Genetics and Breeding, Plovdiv, Bulgaria, 27-31 July 1993, pp. 55-58.

Gordon, T. R., \& Duniway, J. M. (1982). Effects of powdery mildew infection on the efficiency of $\mathrm{CO}_{2}$ fixation and light utilization by sugar beet leaves. Plant Physiology, 69, 139-142.

Grandillo, S., Chetelat, R., Knapp, S. K., Spooner, D. M., Peralta, I., Cammareri, M., Perez, O., Termolino, P., Tripode, P., Chiusano, M. L., Ercolano, M. R., Fruschiante, L., Monte, L., \& Pignone, D. (2011). Solanum section Lycopersicon. In C. Kole (Ed.), Wild crop relatives: Genomic and breeding resources (Vegetables, Vol. 5, pp. 129-216). Berlin: Springer Verlag.

Gulen, H., \& Eris, A. (2004). Effect of heat stress on peroxidase activity and protein content in strawberry plants. Plant Science, 166, 739-744.

Gustafson, G. D., \& Shaner, G. (1982). Influence of plant age on the expression of slow-mildewing resistance in wheat. Phytopathology, 72, 746-749.

Hannig, Ch. (1996). Untersuchungen zu Oidium lycopersicum, dem Echten Mehltau an Tomate. Freising-Weihenstephan, Germany, Technische Universität München, Germany, Ph.D. Thesis.

Heath, M. C. (2000a). Non-host resistence and nonspecific plant defenses. Current Opinnions in Plant Biology, 3, 315-319.

Heath, M. C. (2000b). Hypersensitive response-related death. Plant Molecular Biology, 44, 321-334.

Heitefuss, R., Ebrahim-Nesbat, F., Ordonez, M. T., \& SchornKasten, K. (1997). Investigations on adult plant resistance 
of barley against Erysiphe graminis f. sp. hordei. Journal of Phytopathology, 145, 177-184.

Heuvelink, E. (Ed.). (2005). Tomatoes. Wallingford, UK: CABI Publishing.

Hiraga, S., Sasaki, K., Ito, H., Ohashi, Y., \& Matsui, H. (2001). A large family of class III plant peroxidases. Plant Cell Physiology, 42, 462-468.

Huang, J.-S. (2001). Plant Pathogenesis and Resistance. Biochemistry and Physiology of Plant-microbe Interactions. Dordrecht, The Netherlands: Kluwer Academic Publisher.

Huang, C. C., Biesheuvel, J., Groot, T., Niks, R., \& Lindhout, P. (1997). Resistance mechanisms to Oidium lycopersicum. Abstracts of the XIII. Meeting EUCARPIA (p. 53). Jerusalem, Izrael: Tomato Working Group.

Huang, C., Groot, T., Meijer-Dekens, F., Niks, R., \& Lindhout, P. (1998). Hypersensitivity is the major mechanism of resistance to powdery mildew (Oidium lycopersicum) in Lycopersicon species. European Journal of Plant Pathology, 104, 399-407.

Huang, C. C., Biesheuvel, J., Lindhout, P., \& Niks, R. E. (2000a). Host range of Oidium lycopersici occurring in the Netherlands. European Journal of Plant Pathology, 106, 465-473.

Huang, C. C., Hoefs-van de Putte, P. M., Haanstra-van der Meer, J. G., Meijer-Deckens, F., \& Lindhout, P. (2000b). Characterization and mapping of resistance to Oidium lycopersicum in two Lycopersicon hirsutum accessions: evidence for close linkage of two $\mathrm{Ol}$-genes on chromosome 6 of tomato. Heredity, 85, 511-520.

Hückelhoven, R., \& Kogel, K. H. (2003). Reactive oxygen intermediates in plant-microbe interactions: Who is who in powdery mildew resistance? Planta, 216, 891-902.

Ignatova, S. I., Gorshkova, N. S., \& Tereshonkova, T. A. (1997). Powdery mildew of tomato and sources of resistance. Abstract XII. Meet. EUCARPIA (p. 79). Jerusalem, Izrael: Tomato Working Group.

Jacob, D., Rav-David, D., Sztjenberg, A., \& Elad, Y. (2008). Conditions for development of powdery mildew of tomato caused by Oidium neolycopersici. Phytopathology, 98, 270-281.

Jankovics, T., Bai, Y., Kovacs, G. M., Bardin, M., Nicot, P. C., Toyoda, H., Matsuda, Y., Niks, R. E., \& Kiss, L. (2008). Oidium neolycopersici: Intra-specific variability inferred from AFLP analysis and relationship with closely related powdery mildew fungi infecting various plant species. Phytopathology, 98, 529-540.

Jarvis, W. R., Gubler, W. D., \& Grove, G. G. (2002). Epidemiology of powdery mildews in agricultural pathosystems. In R. R. Bélanger, W. R. Bushnell, A. J. Dik, \& T. L. W. Carver (Eds.), The Powdery Mildews-A Comprehensive Treatise (pp. 169-199). St Paul, MN, USA: APS Press.

Ji, Y., \& Scott, J. W. (2007). Tomato. In R. J. Singh (Ed.), Genetic Resources, Chromosome Engineering, and Crop Improvement (Vol. 3, pp. 59-113). Boca Raton, USA: Vegetable Crops. CRC Press.

Jones, H. E., Whipps, J. M., Thomas, B. J., Carver, T. L. W., \& Gurr, S. J. (2000). Initial events in the colonisation of tomatoes by Oidium lycopersici, a distinct powdery mildew fungus of Lycopersicon species. Canadian Journal of Botany, 78, 1361-1366.
Kashimoto, K., Matsuda, Y., Matsutani, K., Sameshima, T., Kakutani, K., Nonomura, T., Okada, K., Kusakari, S., Nakata, K., Takamatsu, S., \& Toyoda, H. (2003a). Morphological and molecular characterization for a Japanese isolate of tomato powdery mildew Oidium neolycopersici and its host range. Journal of General Plant Pathology, 69, 176-185.

Kashimoto, K., Sameshima, T., Matsuda, Y., Nonomura, T., Oichi, W., Kakutani, K., Nakata, K., Kusakari, S., \& Toyoda, H. (2003b). Infectivity of a Japanese isolate of Oidium neolycopersici KTP-01 to a European tomato cultivar resistant to O. lycopersici. Journal of General Plant Pathology, 69, 406-408.

Kenyon, D. M., Dixon, G. R., \& Helfer, S. (2002). Effects of relative humidity, light intensity and photoperiod on the colony development of Erysiphe sp. on Rhododendron. Plant Pathology, 1, 103-108.

Kiss, L., Cook, R. T. A., Saenz, G. S., Cunnington, J. H., Takamatsu, S., Pasce, I., Bardin, M., Nicot, P. C., Sato, Y., \& Rossman, A. Y. (2001). Identification of two powdery mildew fungi, Oidium neolycopersici sp. nov. and $O$. lycopersici, infecting tomato in different parts of the world. Mycological Research, 105, 684-697.

Kiss, L., Takamatsu, S., \& Cunnington, J. H. (2005). Molecular identifications of Oidium neolycopersici as the causal agent of the recent tomato powdery mildew epidemics in the North America. Plant Disease, 89, 491-496.

Kiss, L., Pintye, A., Zséli, G., Jankovics, T., Szentiványi, O., Hafez, J. M., \& Cook, R. T. A. (2010). Microcyclic conidiogenesis in powdery mildews and its association with intracellular parasitism by Ampelomyces. European Journal of Plant Pathology, 126, 445-451.

Knapp, S., Bohs, L., Nee, M., \& Spooner, D. M. (2004). Solanaceae - a model for linking genomics with biodiversity. Comparative and Functional Genomics, 5, 285-291.

Koike, S. T., Gladders, P., \& Paulu, A. O. (2007). Vegetable Diseases. A Color Handbook. Boston and San Diego, USA: Academic. 448 pp.

Kovács, G. M., Jankovics, T., \& Kiss, L. (2011). Variation in the nrDNA ITS sequences of some powdery mildew species: do routine molecular identification procedures hide valuable information? European Journal of Plant Pathology, 131, 135-151.

Kozik, E. (1993). Resistance to powdery mildew, "Oidium lycopersici" in tomato. Tomato Genetics Cooperative Report, 43, 26-27.

Kranz, J. (2003). Comparative Epidemiology of Plant Diseases. Berlin, Heidelberg, New York: Springer. 206 pp.

Kumar, V., Singh, B., Sugha, S. K., \& Basandrai, A. K. (1995). Sources of resistance to tomato powdery mildew. Indian Journal of Mycology and Plant Pathology, 25, 172-174.

Kunoh, H. (1995). Host-parasite specificity in powdery mildews. In K. Kohmoto, U. S. Singh, \& R. P. Singh (Eds.), Pathogenesis and host specificity in plant diseases (Vol. II, pp. 239-250). Oxford: Eukaryotes, Pergamon, Elsevier Science.

Lamb, C., \& Dixon, R. (1997). The oxidative burst in plant disease resistance. Annual Review of Plant Physiology and Plant Molecular Biology, 48, 251-275.

Lebeda, A. (1984). A contribution to the general theory of hostparasite specificity. Phytopathologische Zeitschrift, 110, 226-234. 
Lebeda, A., \& Jendrulek, T. (1988). Application of methods of multivariate analysis in comparative epidemiology and research into field resistance. Zeitschrift für Pflanzenkrankheiten und Pflanzenschutz, 95, 495-505.

Lebeda, A., \& Mieslerová, B. (1999). Identification, occurrence and host range of tomato powdery mildew (Oidium lycopersici) in the Czech Republic. Acta Phytopathologica et Entomologica Hungarica, 34, 13-25.

Lebeda, A., \& Mieslerová, B. (2000). Case study of hostpathogen interaction: tomato (Lycopersicon spp.) - tomato powdery mildew (Oidium lycopersici). Plant Protection Science, 36, 156-162.

Lebeda, A., \& Mieslerová, B. (2002). Variability in pathogenicity of Oidium neolycopersici on Lycopersicon species. Journal of Plant Diseases and Protection, 109, 129-141.

Lebeda, A., Luhová, L., Sedlářová, M., \& Jančová, D. (2001a). The role of enzymes in plant - fungal pathogens interactions. Journal of Plant Disease and Protection, 108, 89-111.

Lebeda, A., Pink, D. A. C., \& Mieslerová, B. (2001b). Hostparasite specificity and defense variability in the Lactuca spp.-Bremia lactucae pathosystem. Journal of Plant Pathology, 83, 25-35.

Lebeda, A., Mieslerová, B., Luhová, L., \& Mlíčková, K. (2002). Resistance mechanisms in Lycopersicon spp. to tomato powdery mildew (Oidium neolycopersici). Plant Protection Science, 38(Special Issue 1), 141-144.

Lebeda, A., Sedlářová, M., Lynn, J., \& Pink, D. A. C. (2006). Phenotypic and histological expression of different genetic backgrounds in interactions between lettuce, wild Lactuca spp., L. sativa $\times$ L. serriola hybrids and Bremia lactucae. European Journal of Plant Pathology, 115, 431-441.

Leitner, M., Vandelle, E., Gaupels, F., Bellin, D., \& Delledonne, M. (2009). NO signals in the haze: nitric oxide signalling in plant defence. Current Opinion in Plant Biology, 12, 451-458.

Lemaire, J.-M., Conus, M., Burgerjon, A., \& Mas, P. (1999). Oidium lycopersicon, un nouvel oidium de la tomate. PHM Revue Horticole, 402, 21-24.

Leveillé, J. H. (1851). Organisation et disposition méthodique des espéces qui composent le genre Érysiphe. Annales des Sciences Naturelles; Botanique. (sér. 3), 15, 109-179.

Li, C., Bai, Y., Jacobsen, E., Visser, R., Lindhout, P., \& Bonnema, G. (2006). Tomato defense to the powdery mildew fungus: differences in expression of genes in susceptible, monogenic- and polygenic resistance responses are mainly in timing. Plant Molecular Biology, 62, 127-140.

Li, C., Bonnema, G., Che, D., Dong, L., Lindhout, P., Visser, R., \& Bai, Y. (2007). Biochemical and molecular mechanisms involved in monogenic resistance responses to tomato powdery mildew. Molecular and Plant Microbe Interaction, 20, 1161-1172.

Li, C. W., Pei, D. L., Wang, W. J., Ma, Y. S., Wang, L., Wang, F., \& Liu, J. L. (2008). First report of powdery mildew caused by Oidium neolycopersici on tomato in China. Disease Notes, 92, 1370.

Li, C., Faino, L., Dong, L., Fan, J., Kiss, L., De Giovanni, C., Lebeda, A., Scott, J., Matsuda, Y., Toyoda, H., Lindhout, P., Visser, R. G., Bonnema, G., \& Bai, Y. (2012). Characterization of polygenic resistance to powdery mildew in tomato at cytological, biochemical and gene expression level. Molecular Plant Patholology, 13, $148-159$.
Lindhout, P., Beek, H., \& Pet, G. (1994a). Wild Lycopersicon species as sources for resistance to powdery mildew: mapping of resistance gene $\mathrm{Ol-1}$ on chromosome 6 of lycopersicon hirsutum. Acta Horticulturae, 376, 387-394.

Lindhout, P., Pet, G., \& Beek, H. (1994b). Screening wild Lycopersicon species for resistance to powdery mildew (Oidium lycopersicum). Euphytica, 72, 43-49.

Macnab, A. A., \& Sherf, A. F. (1986). Vegetable Diseases and Their Control (2nd ed.). New York: John Wiley \& Sons.

Magyarosy, A. C., Schürmann, P., \& Buchanan, B. B. (1976). Effect of powdery mildew infection on photosynthesis by leaves and chloroplasts of sugar beets. Plant Physiology, 57, 486-489.

Matsuda, Y., Mori, Y., Sakano, Y., Nishida, M., Tarumoto, K., Nonomura, T., Nishimura, H., Kusakari, S.-I., \& Toyoda, H. (2005). Screening of wild Lycopersicon species for resistance to Japanese isolate of tomato powdery mildew Oidium neolycopersici. Breeding Science, 55, 355-360.

Mieslerová, B., \& Lebeda, A. (1999). Taxonomy, distribution and biology of tomato powdery mildew (Oidium lycopersici). Journal of Plant Diseases and Protection, 106, 140-157.

Mieslerová, B., \& Lebeda, A. (2010). Influence of temperature and light conditions on germination, growth and conidiation of Oidium neolycopersici. Journal of Phytopathology, 158, 616-627.

Mieslerová, B., Lebeda, A., \& Chetelat, R. T. (2000). Variation in response of wild Lycopersicon and Solanum spp. against tomato powdery mildew (Oidium lycopersici). Journal of Phytopathology, 148, 303-311.

Mieslerová, B., Lebeda, A., Kennedy, R., \& Novotný, R. (2002). Comparative morphological studies on tomato powdery mildew (Oidium lycopersici). Acta Phytopathologica et Entomologica Hungarica, 37, 57-74.

Mieslerová, B., Lebeda, A., \& Kennedy, R. (2004). Variation in Oidium neolycopersici development on host and non-host plant species and their tissue defence response. Annals of Applied Biology, 144, 237-248.

Mieslerová, B., Lebeda, A., \& Vaculíková, I. (2006). The effect of temperature on development of tomato powdery mildew (Oidium neolycopersici) and on expression of host plant resistance. In G. Herda, J. Mazáková, \& M. Zouhar (Eds.), Proceedings of the XVIIth Czech and Slovak Plant Protection Conference, Praha, Czech Republic, 12-14 Sep 2006, pp. 287-291.

Milotay, P., \& Dormanns-Simon, E. (1997). Powdery mildew on tomato in Hungary and some possible sources of resistance. Abstract XII. Meet. EUCARPIA (p. 60). Jerusalem, Izrael: Tomato Working Group.

Mličková, K., Luhová, L., Lebeda, A., Mieslerová, B., \& Peč, P. (2004). Reactive oxygen species generation and peroxidase activity during Oidium neolycopersici infection on Lycopersicon species. Plant Physiology and Biochemistry, 42, 753-761.

Morel, J.-B., \& Dangl, J. L. (1997). The hypersensitive response and the induction of cell death in plants. Cell Death and Differentiation, 4, 671-683.

Moriondo, M., Orlandini, S., Giuntoli, A., \& Bindi, M. (2005). The effect of downy and powdery mildew on grapevine (Vitis vinifera L.) leaf gas exchange. Journal of Phytopathology, 153, 350-357. 
Mur, L. A., Carver, T. L., \& Prats, E. (2006). NO way to live; the various roles of nitric oxide in plant-pathogen interactions. Journal of Experimental Botany, 57, 489-505.

Mysore, K. S., \& Ryu, C. M. (2004). Non-host resistance: how much do we know? Trends in Plant Science, 9, 97-104.

Niks, R., \& Marcel, T. (2009). Non-host and basal resistance: how to explain specificity? New Phytologist, 182, 817-828.

Nonomura, T., Xu, L., Wada, M., Kawamura, S., Miyajima, T., Nishitomi, A., Kakutani, K., Takikawa, Y., Matsuda, Y., \& Toyoda, H. (2009). Trichome exudates of Lycopersicon pennellii form a chemical barrier to suppress leaf-surface germination of Oidium neolycopersici conidia. Plant Science, 176, 31-37.

Nonomura, T., Nishitomi, A., Matsuda, Y., Soma, C., Xu, L., Kakutani, K., Takikawa, Y., \& Toyoda, H. (2010). Polymorphic change of appressoria by the tomato powdery mildew Oidium neolycopersici on host tomato leaves reflects multiple unsuccessful penetration attempts. Fungal Biology, 114, 917-928.

Noordeloos, M. E., \& Loerakker, W. M. (1989). Studies in plant pathogenic fungi. II. On some powdery mildews (Erysiphales) recently recorded from The Netherlands. Persoonia, 14, 51-60.

Oichi, W., Matsuda, Y., Nonomura, T., \& Toyoda, H. (2006). Formation of conidial pseudochains by tomato powdery mildew Oidium neolycopersici. Plant Disease, 90, 915919.

Orozco-Cardenas, M., \& Ryan, C. A. (2002). Nitric oxide negatively modulates wound signalling in tomato plants. Plant Physiology, 130, 487-493.

Parlevliet, J. E. (1979). Components of resistance that reduce the rate of epidemic development. Annual Review of Phytopathology, 17, 203-222.

Pei, D., Ma, H., Zhang, Y., Ma, Y., Wang, W., Geng, H., Wu, J., \& Li, C. (2011). Virus-induced gene silencing of a putative glutathione S-Transferase gene compromised $\mathrm{Ol}$-1-mediated resistance against powdery mildew in tomato. Plant Molecular Biological Report, 29, 972-978.

Peralta, I. E., \& Spooner, D. M. (2005). Morphological characterization and relationships of wild tomatoes (Solanum L. Section Lycopersicon). Monographs in Systematic Botany from the Missouri Botanical Garden, 104, 227-257.

Peralta, I. E., Knapp, S., \& Spooner, D. M. (2005). New species of wild tomatoes (Solanum Section Lycopersicon: Solanaceae) from Northern Peru. Systematic Botany, 30, 424- 434.

Peralta, I. E., Spooner, D. M., \& Knapp, S. (2008). Taxonomy of wild tomatoes and their relatives (Solanum sect. Lycopersicoides, sect. Juglandifolia, sect. Lycopersicon; Solanaceae) (Systematic Botany Monographs, Vol. 84, p. 186). Ithaca, New York: Cornell University.

Piterková, J., Petřivalský, M., Luhová, L., Mieslerová, B., Sedlářová, M., \& Lebeda, A. (2009). Local and systemic production of nitric oxide in tomato responses to powdery mildew infection. Molecular Plant Pathology, 10, 501-513.

Piterková, J., Hofman, J., Mieslerová, B., Sedlářová, M., Luhová, L., Lebeda, A., \& Petřivalský, M. (2011). Dual role of nitric oxide in Solanum spp.-Oidium neolycopersici interaction. Environmental and Experimental Botany, 74, 37-44.

Poysa, V. (1990). The development of bridge lines for interspecific gene transfer between Lycopersicon esculentum and $L$. peruvianum. Theoretical and Applied Genetics, 79, 187-192.
Prats, E., Mur, L. A. J., Sanderson, R., \& Carver, T. L. W. (2005). Nitric oxide contributes both to papilla-based resistance and the hypersensitive response in barley attacked by Blumeria graminis f. sp. hordei. Molecular Plant Pathology, 6, 65-78.

Prokopová, J., Mieslerová, B., Hlaváčková, V., Hlavinka, J., Lebeda, A., Nauš, J., \& Špundová, M. (2010). Changes in photosynthesis of Lycopersicon spp. plants induced by tomato powdery mildew infection in combination with heat shock pre-treatment. Physiological and Molecular Plant Pathology, 74, 205-213.

Rick, C. M. (1979). Biosystematic studies in Lycopersicon and closely related species of Solanum. In J.G. Hawkes, R.N. Lester, \& A.D. Skelding (Eds.), The biology and taxonomy of the Solanaceae, Linnean Society Symposium Series (7, pp. 667-678). Academic Press, London.

Rick, C. M. (1995). Tomato, Lycoperscion esculentum (Solanaceae). In J. Smart \& N. W. Simmonds (Eds.), Evolution of crop plants (2nd ed., pp. 452-457). Harlow: Longman Scientific \& Technical.

Ridout, C. J. (2009). 3. Profiles in pathogenesis and mutualism: powdery mildews. In K. Esser, H. B. Deising, \& The Mycota (Eds.), Plant Relationships (2nd ed., Vol. V, pp. 50-67). Berlin, Heidelberg, Germany: Springer.

Roberts, A. M., \& Walters, D. R. (1988). Photosynthesis in discrete regions of leek leaves infected with the rust, Puccinia allii Rud. New Phytologist, 110, 371-376.

Robert-Seilaniantz, A., Grant, M., \& Jones, J. D. G. (2011). Hormone crosstalk in plant disease and defense: more than just jasmonate-salicylate antagonism. Annual Review of Phytopathology, 49, 317-343.

Rubatzky, V. E., \& Yamaguchi, M. (1997). World Vegetables (2nd ed.). New York: Chapman \& Hall.

Sabri, N., Dominy, P. J., \& Clarke, D. D. (1997). The relative tolerance of wild and cultivated oats to infection by Erysiphe graminis f. sp. avenae: II. The effects of infection on photosynthesis and respiration. Physiological and Molecular Plant Pathology, 50, 321-335.

Saenz, G. S., \& Taylor, J. W. (1999). Phylogeny of the Erysiphales (powdery mildews) inferred from internal transcribed spacer (ITS) ribosomal DNA sequences. Canadian Journal of Botany, 77, 150-169.

Salmon, E. S. (1900). Monograph of the Erysiphaceae. New York: Memoirs of the Torrey Botanical Club, 9, 1-292.

Scholes, J. D., Lee, P. J., Horton, P., \& Lewis, D. H. (1994). Invertase: understanding changes in the photosynthetic and carbohydrate metabolism of barley leaves infected with powdery mildew. New Phytologist, 126, 213-222.

Schweizer, P., Vallélian-Bindschedler, L., \& Mosinger, E. (1995). Heat-induced resistance in barley to the powdery mildew fungus Erysiphe graminis f. sp. hordei. Physiological and Molecular Plant Pathology, 47, 51-66.

Sedlářová, M., Petřivalský, M., Piterková, J., Luhová, L., Kočírová, J., \& Lebeda, A. (2011). Influence of nitric oxide and reactive oxygen species on development of lettuce downy mildew in Lactuca spp. European Journal of Plant Pathology, 129, 267-280.

Seifi, A., Kaloshian, I., Vossen, J., Che, D., Bhattarai, K. K., Fan, J., Naher, Z., Goverse, A., Tjallingii, W. F., Lindhout, P., Visser, R. G., \& Bai, Y. (2011). Linked, if not the same, Mi-1 homologues confer resistance to tomato powdery mildew and root- 
knot nematodes. Molecular Plant-Microbe Interactions, 24, $441-450$

Seifi, A., Gao, D., Zheng, Z., Pavan, S., Visser, R.G.F., Wolters, AM.A., \& Bai, Y. (2013). Genetics and molecular mechanisms of resistence to powdery mildews in tomato (Solanum lycopersicum) and its wild relatives. European Journal of Plant Pathology (in press).

Shaner, G. (1973). Evaluation of slow-mildewing resistance of Knox wheat in the field. Phytopathology, 63, 867872.

Smith, V. L., Douglas, S. M., \& LaMondia, J. A. (1997). First report of powdery mildew of tomato caused by an Erysiphe sp. in Connecticut. Plant Disease, 81, 229.

Spanu, P. D. (2012). The Genomics of Obligate (and Nonobligate) Biotrophs. Annual Review of Phytopathology, 50, 91-109.

Spooner, D. M., Peralta, I., \& Knapp, S. (2005). Comparison of AFLPs with other markers for phylogenetic inference in wild tomatoes Solanum L. section Lycopersicon (Mill.) Wettst. Taxon, 54, 43-61.

Swarbrick, P. J., Schulze-Lefert, P., \& Scholes, J. D. (2006). Metabolic consequences of susceptibility and resistance (race-specific and broad-spectrum) in barely leaves challenged with powdery mildew. Plant, Cell and Environment, 29, 1061-1076.

Tada, Y., Mori, T., Shinogi, T., Yao, N., Takahashi, S., Betsuyaku, S., Sakamoto, M., Park, P., Nakayashiki, H., Tosa, Y., \& Mayama, S. (2004). Nitric oxide and reactive oxygen species do not elicit hypersensitive cell death but induce apoptosis in the adjacent cells during the defense response of oat. Molecular Plant Microbe Interactions, 17, 245-253.

Takamatsu, S., Hirata, T., Sato, Y., \& Nomura, Y. (1999). Phylogenetic relationships of Microsphaera and Erysiphe sect. Erysiphe (powdery mildews) inferred from the rDNA ITS sequences. Mycoscience, 40, 259-268.

Takikawa, Y., Xu, L., Kakutani, K., Nonomura, T., Sameshima, T., Matsuda, Y., \& Toyoda, H. (2011). Conidia of the tomato powdery mildew Oidium neolycopersici initiate germ tubes at a predetermined site. Mycoscience, 52, 198203.

Thaler, J. S., Humphrey, P. T., \& Whiteman, N. K. (2012). Evolution of jasmonate and salicylate signal crosstalk. Trends in Plant Science, 17, 260-270.

Tománková, K., Luhová, L., Petřivalský, M., Peč, P., \& Lebeda, A. (2006). Biochemical aspects of reactive oxygen species formation in the interaction between Lycopersicon spp. and Oidium neolycopersici. Physiological and Molecular Plant Pathology, 68, 22-32.

Torres, M. A., Jones, J. D. G., \& Dangl, J. L. (2006). Reactive oxygen species signalling response to pathogens. Plant Physiology, 141, 373-378.

Towsend, G. R., \& Heuberger, W. (1943). Methods for estimating losses caused by diseases in fungicide experiments. Plant Disease Report, 27, 340-343.
Vallélian-Bindschedler, L., Schweizer, P., Mosinger, E., \& Metraux, J.-P. (1998). Heat-induced resistance in barley to powdery mildew (Blumeria graminis f.sp. hordei) is associated with a burst of active oxygen species. Physiological and Molecular Plant Pathology, 52, 185-199.

Vandana, S., Sustmann, R., Rauen, U., \& Stöhr, C. (2012). FNOCT as a fluorescent probe for in vivo localization of nitric oxide distribution in tobacco roots. Plant Physiology and Biochemistry, 59, 80-89.

Wendehenne, D., Durner, J., \& Klessig, D. F. (2004). Nitric oxide: a new player in plant signalling and defence responses. Current Opinnions of Plant Biology, 7, 449-455.

Whipps, J. M., \& Budge, S. P. (2000). Effect of humidity on development of tomato powdery mildew (Oidium lycopersici) in the glasshouse. European Journal of Plant Pathology, 106, 395-397.

Whipps, J. M., \& Helyer, N. L. (1994). Occurrence of powdery mildew on aubergine in West Sussex. Plant Pathology, 43, 230-233.

Whipps, J. M., Budge, S. P., \& Fenlon, J. S. (1998). Characteristics and host range of tomato powdery mildew. Plant Pathology, 47, 36-48.

Wright, A. J., \& Heale, J. B. (1988). Host responses to fungal penetration in Erysiphe graminis f.sp. hordei infections in barley. Plant Pathology, 37, 131-140.

Wright, D. P., Baldwin, B. C., Shepard, M. C., \& Scholes, J. D. (1995a). Source-sink relationships in wheat leaves infected with powdery mildew. I. Alterations in carbohydrate metabolism. Physiological and Molecular Plant Pathology, 47, 237-253.

Wright, D. P., Baldwin, B. C., Shepard, M. C., \& Scholes, J. D. (1995b). Source-sink relationship in wheat leaves infected with powdery mildew. II. Changes in the regulation of the Calvin cycle. Physiological and Molecular Plant Pathology, 47, 255-267.

Yu, M., Yun, B. W., Spoel, S. H., \& Loake, G. J. (2012). A sleigh ride through the SNO: regulation of plant immune function by protein S-nitrosylation. Current Opinion in Plant Biology, 15, 424-430.

Yurina, T. P., Yurina, E. V., Karavaev, V. A., Solntsev, M. K., Kukushina, M. A., \& Ekobena, F. A. P. (1996). Physiological characteristics of wheat leaves in cultivars resistant and susceptible to powdery mildew. Russian Journal of Plant Physiology, 43, 64-69.

Zadoks, J. C., \& Schein, R. D. (1979). Epidemiology and Plant Disease Management. New York and Oxford, USA: Oxford University Press. 427 pp.

Zaninotto, F., La Camera, S., Polverari, A., \& Delledonne, M. (2006). Cross talk between reactive nitrogen and oxygen species during the hypersensitive disease resistance response. Plant Physiology, 141, 379-383.

Zeier, J., Delledonne, M., Mishina, T., Severi, E., Sonoda, M., \& Lamb, C. (2004). Genetic elucidation of nitric oxide signalling in incompatible plant-pathogen interactions. Plant Physiology, 136, 2875-2888. 